\title{
Development and Operation Modes of Hydrogen Fuel Cell Generation System for Remote Consumers' Power Supply
}

\author{
Aleksandr Kulikov ${ }^{1,2}$, Aleksey Loskutov 1,2 (D), Andrey Kurkin ${ }^{3, *}$, Andrey Dar'enkov ${ }^{4}$, Andrey Kozelkov ${ }^{3}$, \\ Valery Vanyaev ${ }^{4}$, Andrey Shahov ${ }^{4}$, Andrey Shalukho 1,2, Rustam Bedretdinov 1,2, Ivan Lipuzhin 1,2 \\ and Evgeny Kryukov ${ }^{1,2}$
}

Citation: Kulikov, A.; Loskutov, A.; Kurkin, A.; Dar'enkov, A.; Kozelkov, A.; Vanyaev, V.; Shahov, A.; Shalukho, A.; Bedretdinov, R.; Lipuzhin, I.; et al. Development and Operation Modes of Hydrogen Fuel Cell Generation System for Remote Consumers' Power Supply. Sustainability 2021, 13, 9355. https://doi.org/10.3390/ su13169355

Academic Editor: Pablo García Triviño

Received: 30 June 2021

Accepted: 16 August 2021

Published: 20 August 2021

Publisher's Note: MDPI stays neutral with regard to jurisdictional claims in published maps and institutional affiliations.

Copyright: (c) 2021 by the authors. Licensee MDPI, Basel, Switzerland. This article is an open access article distributed under the terms and conditions of the Creative Commons Attribution (CC BY) license (https:/ / creativecommons.org/licenses/by/ $4.0 /)$.
1 Department of Electric Power Engineering, Power Supply and Power Electronics, Nizhny Novgorod State Technical University n.a. R.E. Alekseev, 603950 Nizhny Novgorod, Russia; inventor61@mail.ru (A.K.); loskutov@nntu.ru (A.L.); shaluho@nntu.ru (A.S.); bedretdinov@nntu.ru (R.B.); lipuzhin@nntu.ru (I.L.); kryukov@nntu.ru (E.K.)

2 Sirius University of Science and Technology, 354340 Sochi, Russia

3 Department of Applied Mathematics, Nizhny Novgorod State Technical University n.a. R.E. Alekseev, 603950 Nizhny Novgorod, Russia; askozelkov@mail.ru

4 Department of Electrical Equipment, Electric Drive and Automation, Nizhny Novgorod State Technical University n.a. R.E. Alekseev, 603950 Nizhny Novgorod, Russia; darenkov@nntu.ru (A.D.); vanyaev.w@mail.ru (V.V.); andshahov@gmail.com (A.S.)

* Correspondence: aakurkin@nntu.ru

Abstract: At the present stage of electric power industry development, special attention is being paid to the development and research of new efficient energy sources. The use of hydrogen fuel cells is promising for remote autonomous power supply systems. The authors of the paper have developed the structure and determined the optimal composition of a hybrid generation system based on hydrogen fuel cells and battery storage and have conducted studies of its operating modes and for remote consumers' power supply efficiency. A simulation of the electromagnetic processes was carried out to check the operability of the proposed hybrid generation system structure. The simulation results confirmed the operability of the structure under consideration, the calculation of its parameters reliability and the high quality of the output voltage. The electricity cost of a hybrid generation system was estimated according to the LCOE (levelized cost of energy) indicator, its value being 1.17 USD/kWh. The factors influencing the electricity cost of a hydrogen generation system have been determined and ways for reducing its cost identified.

Keywords: hydrogen power source; hydrogen fuel cell; optimization; modeling and simulation

\section{Introduction}

The global trends in the modern electric power industry are decarbonization and decentralization aimed at improving the environmental friendliness, reliability and quality of power supply to consumers [1]. Hydrogen is an important energy carrier of the future because it can be produced from a variety of renewable and nonrenewable resources including in remote places without electricity infrastructure [2]. Fuel cells (FC) are the most promising type of power plant for power production from hydrogen. The key advantages of fuel cells are higher energy efficiency due to reliability (no moving parts), absence of energy conversion intermediate stages (electrical efficiency up to 60\%), harmful emissions and noise [3].

Hydrogen fuel cells are already widely used in the transport industry, space industry, etc. $[4,5]$. However, expanding the range of applications for hydrogen fuel cell power plants is essential to accelerate technology development and reduce production costs.

The paper is devoted to the development of a hydrogen fuel cell generation system (HFCGS) for power supply to remote low-power consumers (up to $3 \mathrm{~kW}$ ). A generation system of such capacity may be needed to supply: 
- $\quad$ consumers along the oil and gas pipelines (for example: electrochemical protection, linear telemechanics, radio relay communication equipment, cleaning device launchers); - $\quad$ stationary railway objects (communication devices, automatic crossing signaling);

- $\quad$ autonomous meteorological and telecommunication stations.

Diesel power plants are now widely used for such systems; however, diesel power plants have a number of disadvantages, such as low efficiency and reliability, the need for frequent maintenance, environmental pollution, noise and vibration.

Hydrogen fuel cells eliminate these problems, and they are promising power sources for remote low-power consumers. Meanwhile, fuel cells have disadvantages such as slow dynamic response, long start-up time and soft discharge characteristic [6]. These problems can be solved by combining fuel cells with a storage system and electricity converters in a hybrid generation system.

Many studies are devoted to the development of mathematical and simulation model or prototypes of hybrid systems based on fuel cells, storage systems and other types of energy sources (usually renewable).

Experimental studies of hybrid systems based on fuel cells and solar photovoltaic panels (PV) with a power of $500 \mathrm{~W}$ and $200 \mathrm{~W}$ are presented in [7] and [8], respectively. The electricity generated by PV is used to power a hydrogen generator. The joint operation of PV and fuel cells is not considered. The concept and prototype of a hybrid system that integrates PV, battery storage and hydrogen fuel cells for power supply of remote telecommunications is described in [9]. This system powers a 12-V load with a power of just under $10 \mathrm{~W}$ during the day. The PV panel is the main source while FCs are only required for relatively short timescales to charge the battery or when inclement weather and PV power is not enough. This study shows that FCs can be a useful alternative to PV or wind in case of the small loads of remote consumers.

One of the areas of research is devoted to improving the structure and development of control systems for fuel cells hybrid systems. The control system of a PV-Fuel cell hybrid system is presented in [10]. In [11], the control system of a PV-Wind-Fuel cell hybrid system was developed. The parameter coordination of renewable energy sources and fuel cells is carried out using a DC bus. Additional DC/DC and AC/DC converters are used to connect the sources to the DC bus. Fuel cells are considered as a backup power source to compensate for fluctuations in the power of PV and wind turbines.

In [12], a single-inductor dual-input single-output boost converter was used to coordinate the sources parameters of stand-alone hybrid PV-Fuel cell system. Compared to using a DC bus, this reduces the number of components and the size of the hybrid system, but it requires a high computational performance of the controller. A hybrid system based on a proton exchange membrane (PEM) fuel cell and storage batteries is presented in [13]. Two DC/DC converters are used to match PEM and battery parameters.

This paper represents a continuation of the research in [14] and presents a hydrogen fuel cell generation system (HFCGS) based on hydrogen fuel cells and battery storage. The HFCGS is designed to power remote consumers with a changing daily load schedule.

The study goal is to develop the structure and select the optimal composition of an HFCGS that provides a minimum number of converters and the size of the system and to study its operation modes and the efficiency of its use as a power supply for remote consumers.

\section{Analysis and Selection of the Hydrogen Fuel Cell Generation System Main Units} 2.1. Fuel Cells

The key element in the structure of the HFCGS is the block of fuel cells, which largely determines the efficiency and reliability of consumer's power supply. When developing the structure and determining the composition of the HFCGS, the most important task is to select the most suitable fuel cells type. 
Fuel cells are classified according to the type of electrolyte, operating temperature and fuel. Considering these parameters, five main types of fuel cells that use hydrogen as a fuel can be singled out:

- fuel cells with a polymer or proton exchange membrane-PEMFC;

- fuel cells with alkaline electrolyte-AFC;

- fuel cells with phosphate electrolyte-PAFC;

- fuel cells with molten carbonate-MCFC;

- fuel cells with solid oxide electrolyte-SOFC.

The main structural features of the fuel cell types are shown in Table 1 [15-19].

Table 1. Structure features of hydrogen fuel cells.

\begin{tabular}{|c|c|c|c|c|c|}
\hline Fuel Cell Type & Electrolyte & Electrode Material & Anodic Reaction & Cathodic Reaction & Critical CO Content in Fuel \\
\hline PEMFC & $\begin{array}{l}\text { Perfluoro-sulfonic acid } \\
\text { (Nafion) }\end{array}$ & $\begin{array}{l}\text { Anode: Pt, PtRu } \\
\text { Cathode: Pt }\end{array}$ & $\mathrm{H}_{2} \rightarrow 2 \mathrm{H}^{+}+2 \mathrm{e}^{-}$ & $0.5 \mathrm{O}_{2}+2 \mathrm{H}^{+}+2 \mathrm{e}^{-} \rightarrow \mathrm{H}_{2} \mathrm{O}$ & $\mathrm{CO}>10-100$ ppm \\
\hline AFC & $\begin{array}{l}\text { Potassium hydroxide, } \\
\text { soaked in a matrix } \mathrm{KOH}\end{array}$ & $\begin{array}{l}\text { Anode: } \mathrm{Ni} \\
\text { Cathode: } \mathrm{Ag}\end{array}$ & $\mathrm{H}_{2}+2 \mathrm{OH} \rightarrow 2 \mathrm{H}_{2} \mathrm{O}+2 \mathrm{e}^{-}$ & $0.5 \mathrm{O}_{2}+\mathrm{H}_{2} \mathrm{O}+2 \mathrm{e}^{-} \rightarrow 2 \mathrm{OH}^{-}$ & $\mathrm{CO}>10 \mathrm{ppm}$ \\
\hline PAFC & $\begin{array}{l}\text { Phosphoric acid soaked } \\
\text { in a matrix }\end{array}$ & $\begin{array}{l}\text { Anode: Pt, PtRu } \\
\text { Cathode: } \mathrm{Pt}\end{array}$ & $\mathrm{H}_{2} \rightarrow 2 \mathrm{H}^{+}+2 \mathrm{e}^{-}$ & $0.5 \mathrm{O}_{2}+2 \mathrm{H}^{+}+2 \mathrm{e}^{-} \rightarrow \mathrm{H}_{2} \mathrm{O}$ & $\mathrm{CO}>0.5 \%$ \\
\hline MCFC & Carbonate solution & $\begin{array}{l}\text { Anode: } \mathrm{Ni}-5 \mathrm{Cr} \\
\text { Cathode: } \mathrm{NiO}(\mathrm{Li})\end{array}$ & $\begin{array}{c}\mathrm{H}_{2}+\mathrm{CO}_{3}{ }^{2-} \rightarrow \mathrm{H}_{2} \mathrm{O}+ \\
\mathrm{CO}_{2}+2 \mathrm{e}^{-}\end{array}$ & $0.5 \mathrm{O}_{2}+\mathrm{CO}_{2}+2 \mathrm{e}^{-} \rightarrow \mathrm{CO}_{3}{ }^{2-}$ & does not poison the catalyst \\
\hline SOFC & $\begin{array}{c}\text { Yttria-stabilized } \\
\text { zirconia, or more } \\
\text { recently, } \\
\text { lanthanide-doped ceria }\end{array}$ & $\begin{array}{c}\text { Anode: Ni-YSZ } \\
\text { Cathode: Lanthanum } \\
\text { strontium manganite } \\
\text { (LSM) }\end{array}$ & $\mathrm{H}_{2}+\mathrm{O}^{2-} \rightarrow \mathrm{H}_{2} \mathrm{O}+2 \mathrm{e}^{-}$ & $0.5 \mathrm{O}_{2}+2 \mathrm{e}^{-} \rightarrow \mathrm{O}^{2-}$ & does not poison the catalyst \\
\hline
\end{tabular}

PEMFCs operate within $60-120^{\circ} \mathrm{C}$ temperature range and are classified as lowtemperature fuel cells. PEMFC are characterized by high efficiency of electricity generation (efficiency up to $60 \%$ ), with a service life of 3000 to $5000 \mathrm{~h}$ [20]. The important advantages of PEMFCs are their high power density, a short start and stop time, a high load change rate within a wide range, ease of operation and the ability to work in a wide range of ambient temperatures [21]. The main disadvantage of PEMFCs is the high requirements for the hydrogen quality (catalysts are susceptible to $\mathrm{CO}$ poisoning due to low temperatures) [22]. Therefore, additional purification of hydrogen may be required when using PEMFCs.

AFC as well as PEMFC refer to low-temperature fuel cells (operating temperature is 50-100 ${ }^{\circ} \mathrm{C}$ ) [23]. AFC technologies are the most studied, therefore their power generation efficiency reaches $60 \%$ and the service life is estimated at 10,000 to $15,000 \mathrm{~h}$. The main advantages of AFCs are similar to PEMFCs. The disadvantage of AFCs is their high sensitivity to $\mathrm{CO}_{2}$, which reacts with the electrolyte and reduces the efficiency of the fuel cell. $\mathrm{CO}_{2}$ can be contained in the air, so the use of AFCs is limited to closed spaces (space environment, submarines).

PAFCs operate at temperatures from 150 to $220^{\circ} \mathrm{C}$ and are classified as mediumtemperature fuel cells. The main advantages of PAFCs are the relative simplicity of their structure, their low electrolyte volatility and their high stability. As a result, PAFC service life is estimated at about $65,000 \mathrm{~h}$. PAFC can use impure $\mathrm{H}_{2}$ as fuel and can tolerate up to $1.5 \%$ CO at operating temp. However, the efficiency of PAFC is about $40 \%$ and is inferior to other types of fuel cells [23].

MCFCs are high-temperature fuel cells that operate at temperatures from 600 to $800{ }^{\circ} \mathrm{C}$. MCFCs have a fairly high efficiency (the efficiency of electricity generation is 50-60\%). MCFCs are less demanding on the purity of hydrogen due to the high operating temperature (catalysts are not susceptible to $\mathrm{CO}$ and $\mathrm{CO}_{2}$ poisoning). The main disadvantages of MCFCs are a short service life (7000-8000 h) due to the destruction of components and corrosion, a slow start-up time and the impossibility of restarting after a stop.

SOFCs are fuel cells with the highest operating temperature from 650 to $1000{ }^{\circ} \mathrm{C}$. SOFCs are characterized by high efficiency of electric power generation (efficiency is about $60 \%$ ). The service life of SOFCs is estimated at over $20,000 \mathrm{~h}$ due to low material 
degradation. High temperatures also allow fuel to be used without special pretreatment and generate combined electric and thermal power. However, SOFCs are characterized by the significant amount of time to reach the optimal operating mode and the impossibility of changing the power generation due to high operating temperatures. This significantly complicates the use of SOFCs in power supply systems.

The results of a comparative analysis of hydrogen fuel cells are shown in Figure 1.

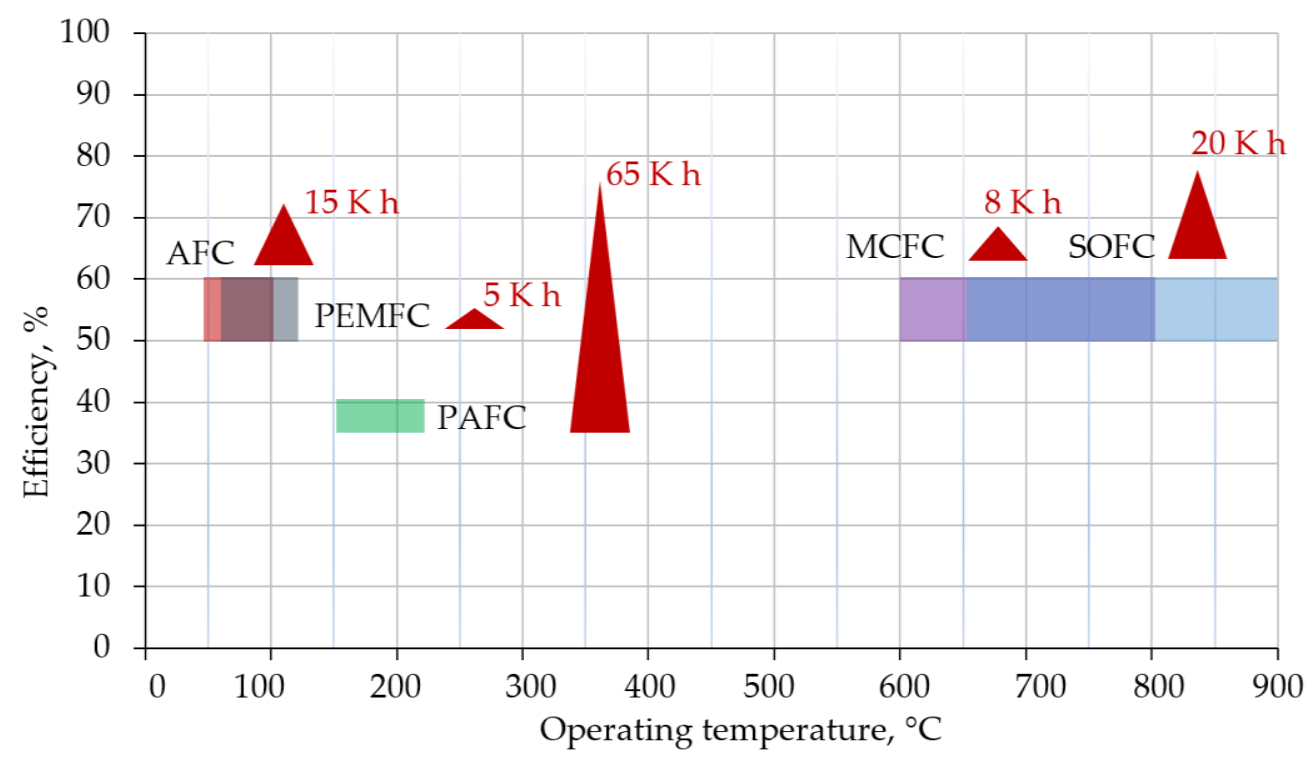

Figure 1. Comparative analysis of hydrogen fuel cells.

The type of fuel cell most suitable for use in an HFCGS is largely determined by the consumer power.

Thus, power supply sources for medium-power consumers (from 10 to $100 \mathrm{~kW}$ ) must provide high energy efficiency and the minimum cost of electricity generated. The priority criteria for selecting a particular type of fuel cell as part of hybrid generation systems are:

- high electricity generation efficiency;

- low requirements for fuel quality (to reduce the cost of special preparation and large fuel volumes processing);

- the possibility of additional use of the heat released by the fuel cell (to increase the overall source efficiency).

Meanwhile, the daily load schedule of medium-power consumers usually changes during the day, but the consumption does not go down beyond a certain level. This makes it possible to continuously stabilize the operating mode of the fuel cell (by using an energy storage system).

Thereafter, it is promising to use high-temperature fuel cells in a hybrid energy complex to supply medium-power consumers (from 10 to $100 \mathrm{~kW}$ ), which allow the use of fuel without special pretreatment and provide combined production of electrical and thermal energy. SOFCs are considered the most efficient in terms of energy performance and service life among high-temperature fuel cells.

Low-power consumers (from 1 to $10 \mathrm{~kW}$ ), in most cases, are characterized by a changing daily load schedule ranging from a decrease in consumption to zero and sharp peaks. Energy sources for such consumers, first of all, must ensure high stability of power supply and duration of autonomous operation. Therefore, the decisive criteria for selecting a fuel cell are a short start and stop time and the ability to quickly change generation over a wide range (for generation schedule to electrical load schedule maximum approximation).

These requirements are met by low-temperature fuel cells-PEMFCs and AFCs. They operate on high quality hydrogen fuel. At the same time, the use of AFCs (due to its 
high sensitivity to $\mathrm{CO}_{2}$ ) is limited to closed spaces (submarines, spacecraft). PEMFCs can operate in a wide temperature range without significant restrictions to environmental conditions (vehicles, low-power stationary consumers, etc.).

The developed HFCGS is designed to power a 3-kW load. Therefore, the most applicable FCs are PEMFCs, which are characterized by a high load change rate, ease of operation and the ability to work in a wide range of ambient temperatures.

\subsection{Battery Storage}

To increase the duration of the HFCGS autonomous operation without refueling, it seems relevant to use a combination of fuel cells with battery storage (BS). BS will ensure the operation of the fuel cells in the most efficient modes at a changing load schedule.

Lithium batteries are the most common. They are characterized by a high energy density and a minimum self-discharge rate, which significantly increases the storage period and extends the service life without deteriorating functional performance. BS must be equipped with a protective controller (BMS board) to prevent the complete loss of the battery cells potential. Lithium batteries are widely used in technology and consumer electronics, electric transport, and also serve as an uninterruptible power supply source.

The main element of any BS is a battery cell. The characteristics of the BS (capacity, reliability and functionality) depend on the parameters of the battery cell. Several types of these can be singled out, depending on the cathodes and electrolytes (Table 2). Lithium polymer batteries were excluded from this comparison as they are fire hazardous when overcharged and overheated.

Table 2. Lithium battery cell parameters.

\begin{tabular}{|c|c|c|c|c|c|}
\hline \multirow{2}{*}{$\begin{array}{c}\text { Type } \\
\text { Type (form factor) }\end{array}$} & \multirow{2}{*}{$\begin{array}{c}\text { Li-Ion } \\
\text { cylindrical }\end{array}$} & \multicolumn{2}{|c|}{$\mathrm{LiFePO}_{4}$} & \multicolumn{2}{|c|}{ LTO } \\
\hline & & cylindrical & prismatic & cylindrical & prismatic \\
\hline Capacity C, Ah & $0.7-7$ & $1.1-50$ & 10-280 & $1.3-40$ & $2.9-23$ \\
\hline Gravimetric energy density, Wh/kg & $120-270$ & $80-140$ & $110-165$ & $70-96$ & $46-90$ \\
\hline Cell voltage, $\mathrm{V}$ & 3.6 & 3.2 & 3.2 & 2.4 & $2.3-2.4$ \\
\hline Standard charge current, C.A & 0.5 & 0.5 & 0.5 & 0.5 & 1.0 \\
\hline Maximum charge current, $C \cdot A$ & 1.0 & 1.0 & 1.0 & 5.0 & 4.0 \\
\hline Long-term discharge current, C.A & 2.0 & $1.0-3.0$ & $1.0-3.0$ & $1.0-5.0$ & $1.0-3.0$ \\
\hline Maximum discharge current, $\mathrm{C} \cdot \mathrm{A}$ & 3.0 & $3.0-5.0$ & $3.0-5.0$ & $5.0-10.0$ & $4.0-10.0$ \\
\hline Service life, cycles (not less) & 1000 & 2000 & 3500 & 10,000 & 15,000 \\
\hline Charge-discharge depth, \%SOC & $20-80$ & $20-80$ & $20-80$ & $0-100$ & $0-100$ \\
\hline Operating temperature (discharge), ${ }^{\circ} \mathrm{C}$ & $-20-+60$ & $-20-+60$ & $-20-+55$ & $-30-+60$ & $-30-+60$ \\
\hline Specific cost, USD/Ah & $1.0-2.5$ & $0.7-3.0$ & $0.5-0.9$ & $0.75-3.0$ & $1.0-2.1$ \\
\hline
\end{tabular}

Figure 2 shows the dependence of gravimetric energy density on the capacity value for various types of battery cells.

Table 2 shows that LTO battery cells are the optimal type of BS for use in standalone power supply systems to remote consumers. They have the highest service life (up to 20,000 cycles), allow for complete battery discharge and can operate in subzero temperatures. However, their high unit cost and low energy intensity (Figure 2) hinder their widespread distribution.

The optimal type of cells for creating an energy storage system is $\mathrm{LiFePO}_{4}$ with an HFCGS power up to $100 \mathrm{~kW}$. $\mathrm{LiFePO}_{4}$ cells are available in a wide range of capacities (from 1.1 to $280 \mathrm{Ah}$ ), have a high efficiency (up to $95 \%$ ) and a service life of more than 2000 cycles (up to 8000 cycles at standard charge-discharge currents). Their main advantages are complete safety (they have thermal and chemical stability) and a long service life. Therefore, 
to create the HFCGS storage system, the cylindrical cells $\mathrm{LiFePO}_{4} 3.2 \mathrm{~V}$ PLB IFR26650-35A, $3500 \mathrm{mAh}$ were selected [24].

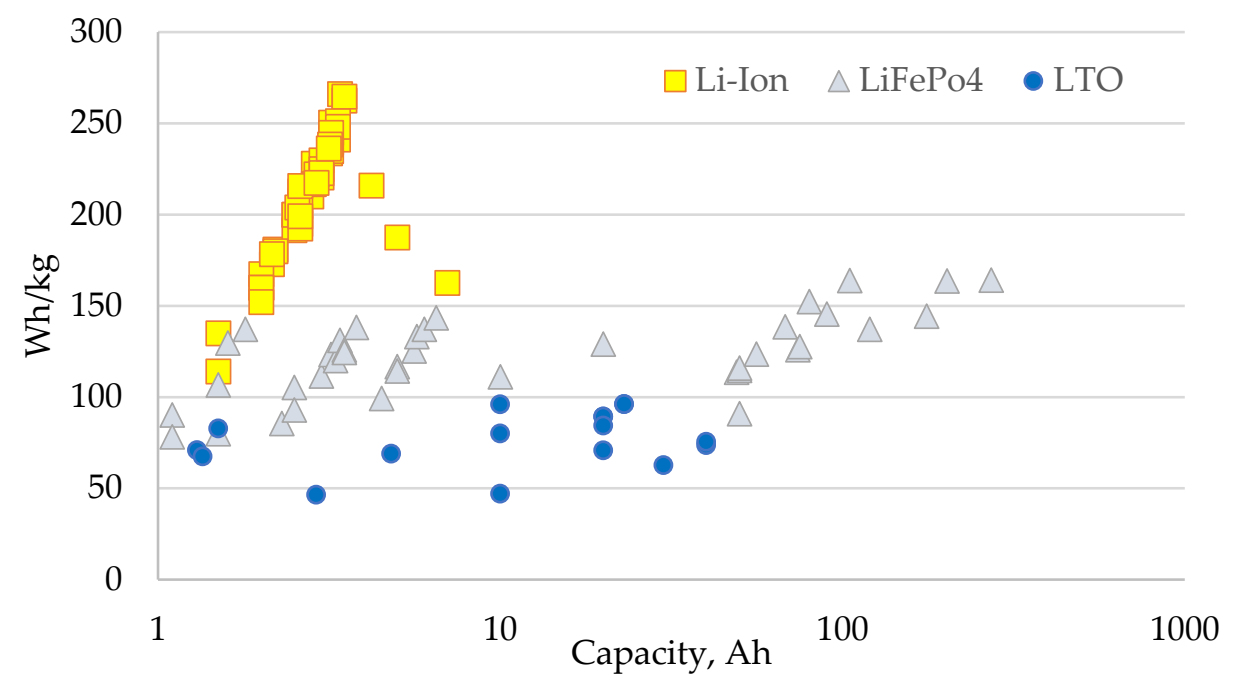

Figure 2. The diagram of the gravimetric energy density dependence on the capacity value for various types of battery cells.

In the power range from 100 to $1000 \mathrm{~kW}$, LTO is preferable due to the high values of the charge-discharge current $(10 \mathrm{C})$ and the high charge rate. However, in order to increase the current, it will be necessary to increase the total capacity of the batteries using parallel LTO cell connections.

\section{Materials and Methods}

Operability and efficiency of the HFCGS depend on the optimal choice of its structural and circuit solutions.

The functional diagram of the developed HFCGS power circuits is shown in Figure 3. The proposed structure provides uninterrupted power supply of the combined resistive and inductive load $Z_{\mathrm{L}}$ from the HFCGS or from the AC mains (if available). Switching the power supply from the HFCGS to the centralized electrical network is carried out by high-speed solid-state relays KV1-KV4 controlled by a microcontroller.

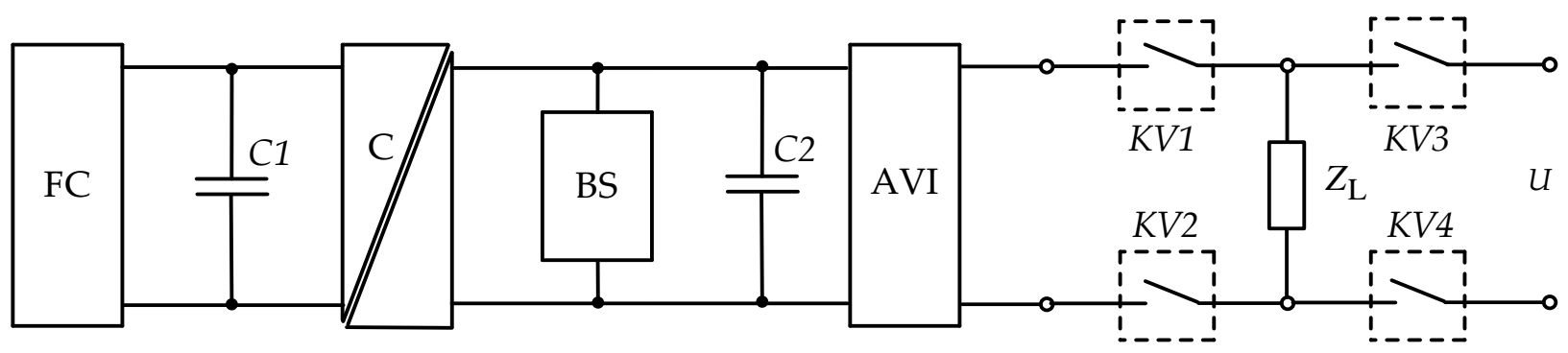

Figure 3. Functional diagram of the HFCGS power circuits.

The HFCGS functional diagram contains fuel cells (FC) and battery storage (BS) based on $\mathrm{LiFePO}_{4}$ batteries. The battery functions as an electric buffer, providing together with the fuel cells the required output power level for a given time. The power circuit also contains a converter (C) and an output autonomous voltage inverter (AVI) with PWM.

The converter matches the relatively low FC voltage level with the increased AVI voltage and also realizes the galvanic isolation of the fuel cells from the remaining power circuit. It is made based on AVI with a latitude regulation of the output voltage and a transformer output. 
The output AVI is made according to a single-phase bridge circuit and operates in unipolar sinusoidal PWM mode, making it possible to reduce the required power consumption of its output filter (in Figure 3, this filter and the EMC filter are included in the AVI structure). The HFCGS converters are based on MOSFETs and IGBTs.

In the developed device, the batteries are connected in series to obtain the voltage that provides the required level of AVI power supply voltage and HFCGS preset output voltage $(220 \mathrm{~V})$, respectively.

"Converter-fuel cell" power circuit section has a feedback system on the output FC power, so on the interval of standby power supply load FC operates in the mode of a constant rated power source.

HFCGS power circuit also contains filter capacitors $C 1$ and $C 2$, which block the AC components generated by the converters.

The main parameters of the HFCGS key units are shown in Table 3. The parameters of each device elements were calculated to develop a HFCGS simulation model.

Table 3. HFCGS key units and parameters.

\begin{tabular}{|c|c|c|c|}
\hline Unit & Symbol (Figure 3) & Type & Nominal Parameters \\
\hline Fuel cell & $\mathrm{FC}$ & PEMFC & $1 \mathrm{~kW}, 46 \mathrm{~V}$ \\
\hline Battery storage & $\mathrm{BC}$ & $\mathrm{LiFePO}_{4}$, cylindrical & $3.5 \mathrm{Ah}, 12 \times 36 \mathrm{~V}$ \\
\hline Converter & C & $\begin{array}{l}\text { single-phase bridge, } \\
\text { MOSFET/IGBT }\end{array}$ & see Section 3.5 \\
\hline $\begin{array}{l}\text { Autonomous voltage } \\
\text { inverter }\end{array}$ & AVI & $\begin{array}{c}\text { single-phase bridge, } \\
\text { MOSFET/IGBT }\end{array}$ & single-phase, $220 \mathrm{~V}$ \\
\hline Filters & $C 1, C 2$ & capacitors & see Section 3.3 \\
\hline Relays & KV1-KV4 & solid-state & - \\
\hline Load & $\mathrm{Z}_{\mathrm{L}}$ & - & $3 \mathrm{~kW}, 220 \mathrm{~V}$ \\
\hline Electrical mains & $\mathrm{U}$ & if applicable & $220 \mathrm{~V}$ \\
\hline
\end{tabular}

\subsection{Calculation of Fuel Cells Internal Resistance}

The discharge characteristic of the selected $48 \mathrm{~V} \mathrm{FC}$ with a power of $1 \mathrm{~kW}$ is shown in Figure 4.

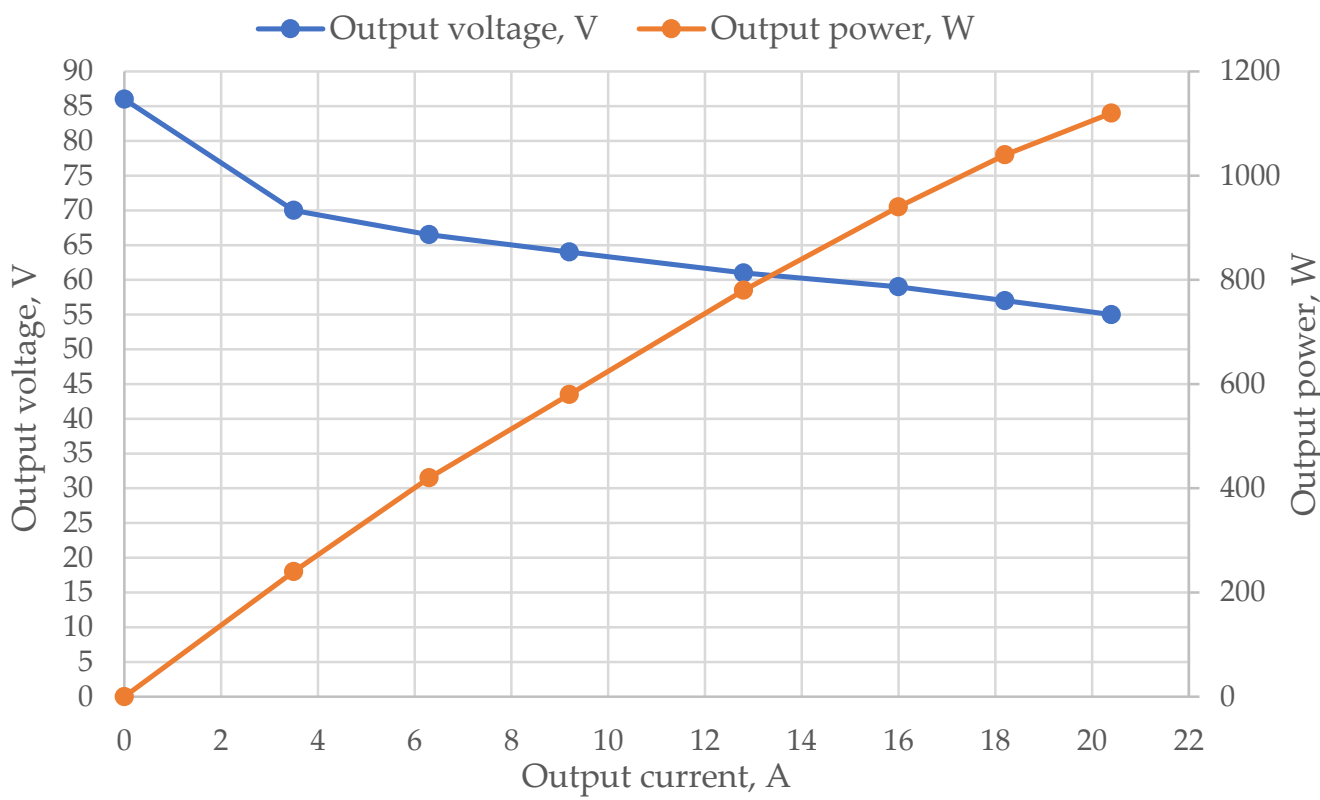

Figure 4. Fuel cell discharge characteristic. 
FC internal resistance $r_{F C}$ according to its discharge characteristic is:

$$
r_{F C}=\frac{\Delta U}{\Delta I}=\frac{70-57}{18.2-3.5}=\frac{13}{14.7}=0.88 \mathrm{Ohm}
$$

\subsection{Battery Storage Parameters Calculation}

To create a HFCGS battery storage system, a series assembly of $12 \mathrm{LiFePO}_{4}$ batteries $36 \mathrm{~V} 3.5 \mathrm{Ah}$ (configuration 12S1P) with BMS boards is used. Table 4 shows the parameters of the battery storage system.

Table 4. HFCGS battery storage system parameters.

\begin{tabular}{cc}
\hline Parameter & Value \\
\hline Capacity C, Ah/kWh & $3.5 / 1.6$ \\
Nominal voltage, $\mathrm{V}$ & 460.8 \\
Maximum voltage $U_{B S \max }, \mathrm{V}$ & 518.4 \\
Minimum voltage $U_{B S \min }, \mathrm{V}$ & 360 \\
Continuous charge current, $\mathrm{A}$ & 3.5 \\
Maximum discharge current, $\mathrm{A}$ & 28 \\
Internal resistance AC $1 \mathrm{kHz} r_{B S \max }, \Omega$ & 2.6 \\
Operating temperature $t^{\circ} \mathrm{C}$ & $-20-+50$ \\
Volumetric Energy Density, $\mathrm{Wh} / \mathrm{L}$ & 306 \\
Gravimetric Energy Density, $\mathrm{Wh} / \mathrm{kg}$ & 125 \\
\hline
\end{tabular}

Figure 5 shows the discharge characteristics of the selected batteries.

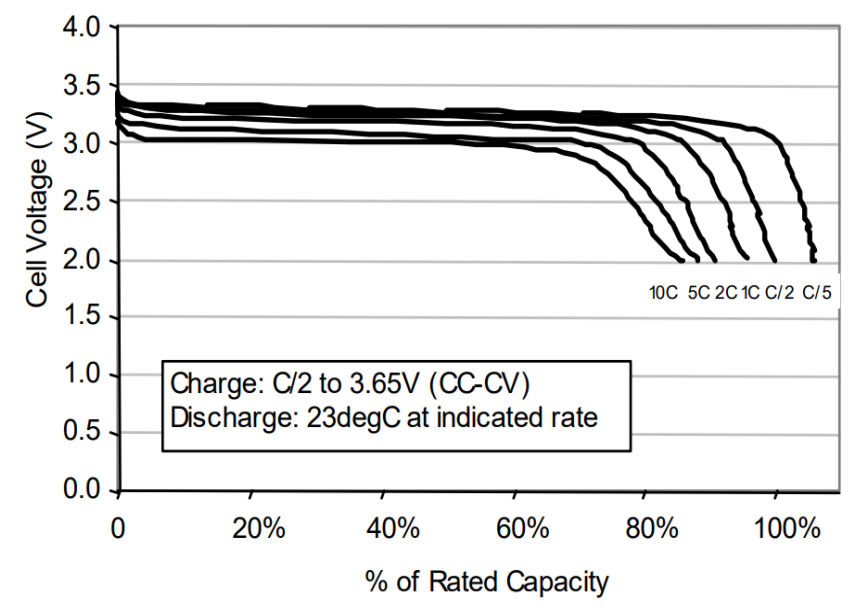

(a)

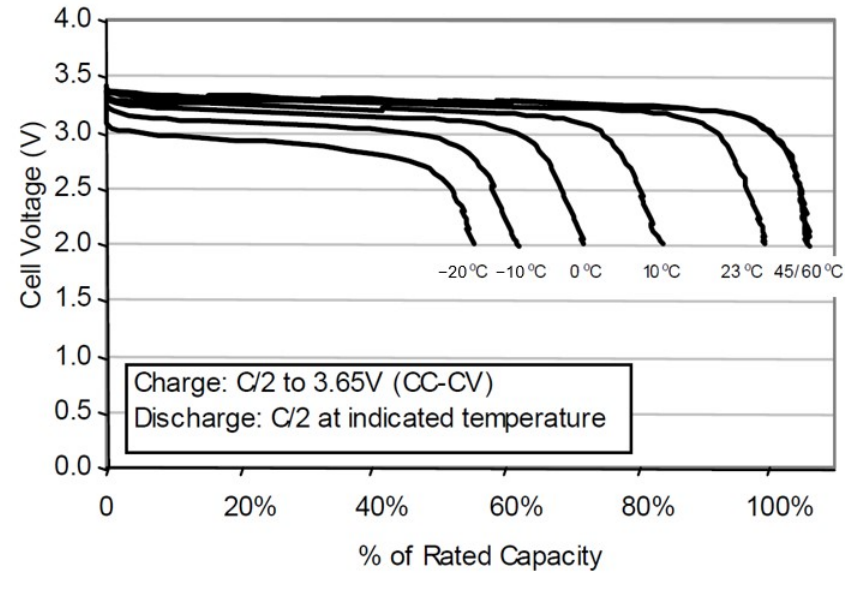

(b)

Figure 5. Discharge characteristics of 3.2 V PLB IFR26650-35A batteries: (a) for various values of ranging from 0.5C to 10.0C; (b) when discharged with a constant current of $0.5 \mathrm{C}$ at various ambient temperatures.

\subsection{Filter Capacitance Values Calculation}

To determine the capacitances, we used the equations describing time dependence on the averaged current consumed by a single-phase bridge AVI with sinusoidal PWM:

$$
\widetilde{i}_{1}=\frac{1}{2} \mu I_{m} \cdot\left[\cos \varphi_{L}-\cos \left(2 \omega t-\varphi_{L}\right)\right],
$$

where $I_{m}$ is amplitude of the averaged output current of a single-phase bridge AVI, $\mu$ is output voltage modulation depth, $\varphi_{L}$ is load current phase angle and $\omega$ is mains voltage angular frequency. 
The maximum value of the amplitude of the variable component of the averaged input current with a circular angular of $2 \omega(f=100 \mathrm{~Hz})$ is:

$$
I_{m \max }=\frac{1}{2} \mu_{\max } I_{m}
$$

The variable component of the averaged input current, i.e., the current generated by the AVI into the power circuit is closed through the battery, FC and filter capacitors $\mathrm{C} 1$ and $C 2$, which causes the pulsations of AVI supply voltage and, as a consequence, distortion of HFCGS output voltage.

Maximum AVI voltage ripple amplitude is determined by the equation:

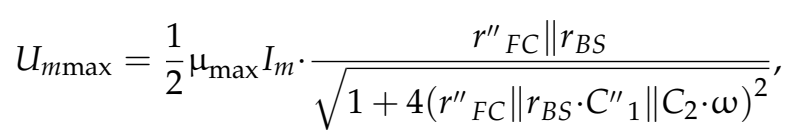

where $r_{F C}^{\prime \prime}$ is the FCs' internal resistance reduced to AVI source voltage; $r_{B S}$ is battery storage internal resistance; $C^{\prime \prime}{ }_{1}$ is $C 1$ capacitance value reduced to AVI source voltage; $C_{2}$ is $C 2$ capacitance; $r^{\prime \prime}{ }_{F C} \| r_{B S}$ and $C^{\prime \prime}{ }_{1} \| C_{2}$ are total resistance and capacitance of parallelconnected elements, respectively.

For real values of the FC and battery parameters, the following relations are valid:

$$
r^{\prime \prime} F C>>r_{B S} ; C^{\prime \prime}{ }_{1}<<C_{2},
$$

And the $U_{m}$ max calculated equation takes on the form:

$$
U_{m \max } \approx \frac{1}{2} \mu_{\max } I_{m} \cdot \frac{r_{B S \max }}{\sqrt{1+4\left(r_{B S \max } C_{2} \omega\right)^{2}}} .
$$

The ripple factor of AVI supply voltage at $100 \mathrm{~Hz}$ frequency is determined by the equation:

$$
k_{U}=\frac{U_{m \max }}{U_{\mathrm{BSmin}}}
$$

By substituting (7) into (6), we obtain an equation for calculating the required value of capacitor $C 2$ providing a given value of the ripple factor:

$$
C_{2}=\frac{1}{2 r_{\mathrm{BS} \max } \omega} \sqrt{\frac{1}{4}\left(\frac{\mu_{\max } I_{m} r_{\mathrm{BS} \max }}{k_{U} U_{\mathrm{BS} \min }}\right)^{2}-1} .
$$

With AVI voltage ripple factor $k_{\mathrm{U}}=0.045$ :

$$
C_{2}=\frac{1}{2 \cdot 2.6 \cdot 314} \sqrt{\frac{1}{4}\left(\frac{0.95 \cdot 24 \cdot 2.6}{0.045 \cdot 360}\right)^{2}-1}=940 \mu \mathrm{F} .
$$

The capacitance value of $C_{2}=1000 \mu \mathrm{F}$ is accepted.

According to (5) an insignificant part of the variable current component generated by AVI into the power circuit is closed through the FC and $C 1$ filter capacitor, and its value has no significant impact on HFCGS output voltage. The required value of $C 1$ capacitance can be selected from the following approximate ratio:

$$
C_{1} \approx \frac{r_{F C}}{r_{B S \max }} \cdot C_{2}
$$

Value of $C 1$ capacitance:

$$
C_{1} \approx \frac{r_{F C}}{r_{B S \max }} \cdot C_{2}=\frac{0.88}{2.6} \cdot 1000=318 \mu \mathrm{F} .
$$


The values of the half-bridge AVI capacitances are taken slightly lower than the calculated ones and equal to $C=2 \cdot C_{1}=470 \mu \mathrm{F}$.

\subsection{AVI Output Voltage Modulation Depth Calculation}

AVI output voltage with PWM modulation depth is determined by the equation:

$$
\mu=\frac{U_{m . o u t}}{U_{B S}},
$$

where $U_{m . o u t}$ is the amplitude of the HFCGS output voltage.

For a given value of the output voltage, the maximum required modulation depth $\mu_{\max }$ calculated value is:

$$
\mu_{\max }=\frac{U_{m . o u t}}{U_{\mathrm{BS} \min }-r_{\text {BSmax }} \cdot \frac{P_{\text {out }}}{U_{\mathrm{BS} \min }}},
$$

where $P_{\text {out }}$ is the power supplied by the HFCGS to the load.

At the effective output voltage value $U_{\text {out }}=220 \mathrm{~V}$ and output power $P_{\text {out }}=3 \mathrm{~kW}$, the maximum required calculated $\mu_{\max }$ value according to (13) is:

$$
\mu_{\max }=\frac{\sqrt{2} \cdot 220}{360-2.6 \cdot \frac{3 \cdot 10^{3}}{360}}=0.92 .
$$

Taking into account voltage drop across the open transistors and dead time of switching AVI transistors, the value of $\mu_{\max }=0.95$ is taken.

\subsection{Converter Output Voltage Boost Coefficient Calculation}

This converter is made on the based on the AVI with a high frequency transformer and matches relatively low fuel cell output voltage to battery voltage. Output voltage boost coefficient $k_{b}$ is calculated in accordance with the equation:

$$
k_{b}=D_{\max } k_{21}=\frac{U_{B S \max }}{U_{F C \min }}
$$

where $D_{\max }$ is the maximum relative duration of switching on converter transistors and $k_{21}$ is the transformation ratio of converter matching transformer.

Coefficient $k_{\mathrm{b}}$ :

$$
k_{b}=D_{\max } k_{21}=\frac{U_{B S \max }}{U_{F C \min }}=\frac{518.4}{57}=9.1 .
$$

Setting the $D_{\max }$ value, the required $k_{21}$ transformation ratio for the AVI bridge circuit is:

$$
k_{21}=\frac{k_{b}}{D_{\max }} .
$$

When using a half-bridge AVI in the converter, the transformation ratio value is calculated by the equation:

$$
\begin{gathered}
k_{21}=\frac{2 k_{b}}{D_{\max }} ; \\
k_{21}=\frac{2 k_{b}}{D_{\max }}=\frac{2 \cdot 9.1}{0.8}=22.8
\end{gathered}
$$

\section{Simulation Modeling of Hydrogen Fuel Cell Generation System Operation Modes}

An electromagnetic processes simulation modeling was carried out in MATLAB Simulink in order to test the operability of the proposed structure of the HFCGS.

The initial data for the modeling and the parameters of the HFCGS power circuit elements are given in Table 5. 
Table 5. Parameters of the HFCGS power circuit elements.

\begin{tabular}{cc}
\hline Parameter & Value \\
\hline Load rated power $\mathrm{P}, \mathrm{kW}$ & 3 \\
Power factor $\cos \varphi_{L}$ & 0.8 \\
The effective value of the HFCGS output & 220 \\
voltage (single phase) $U_{\text {out }}, \mathrm{V}$ & 50 \\
Output voltage frequency $f_{\text {out }}, \mathrm{Hz}$ & 1 \\
FC rated power $P_{F C}, \mathrm{~kW}$ & $360 / 500$ \\
Battery voltage $U_{B S \min } / U_{B S \max }, \mathrm{V}$ & 20 \\
Converters clock frequency $f_{C L}, \mathrm{kHz}$ & $500 / 2$ \\
Output $\mathrm{L}-\mathrm{C}$ filter $\mathrm{L}, \mu \mathrm{H} / \mathrm{C}, \mu \mathrm{F}$ & $235 / 1.0$ and 2.0 \\
Capacities $C_{1}, \mu \mathrm{F} / C_{2}$ and $C_{3}, \mathrm{mF}$ &
\end{tabular}

The autonomous inverter and converter simulation model structures are shown in Figures 6 and 7, respectively.

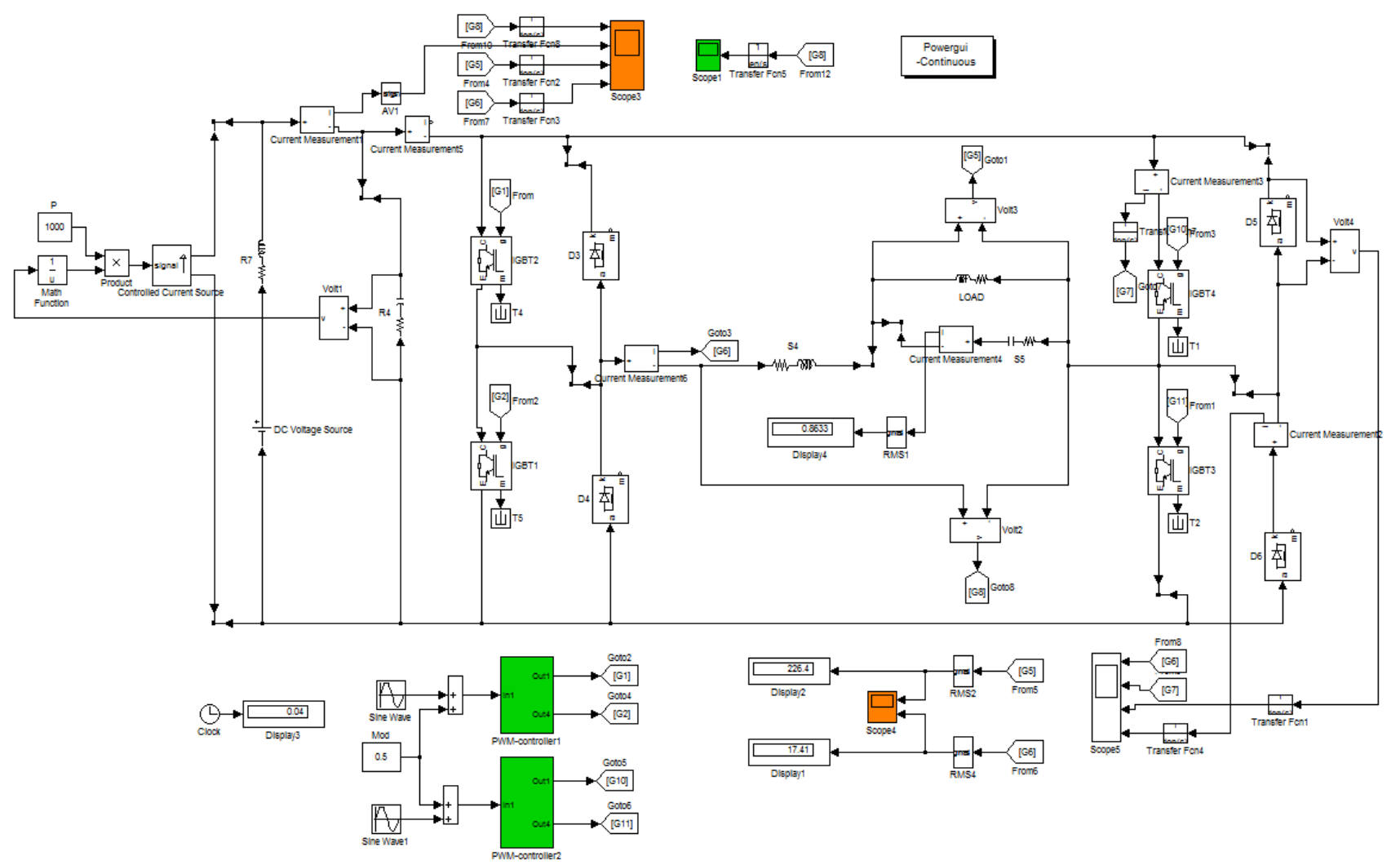

Figure 6. Autonomous inverter simulation model. 


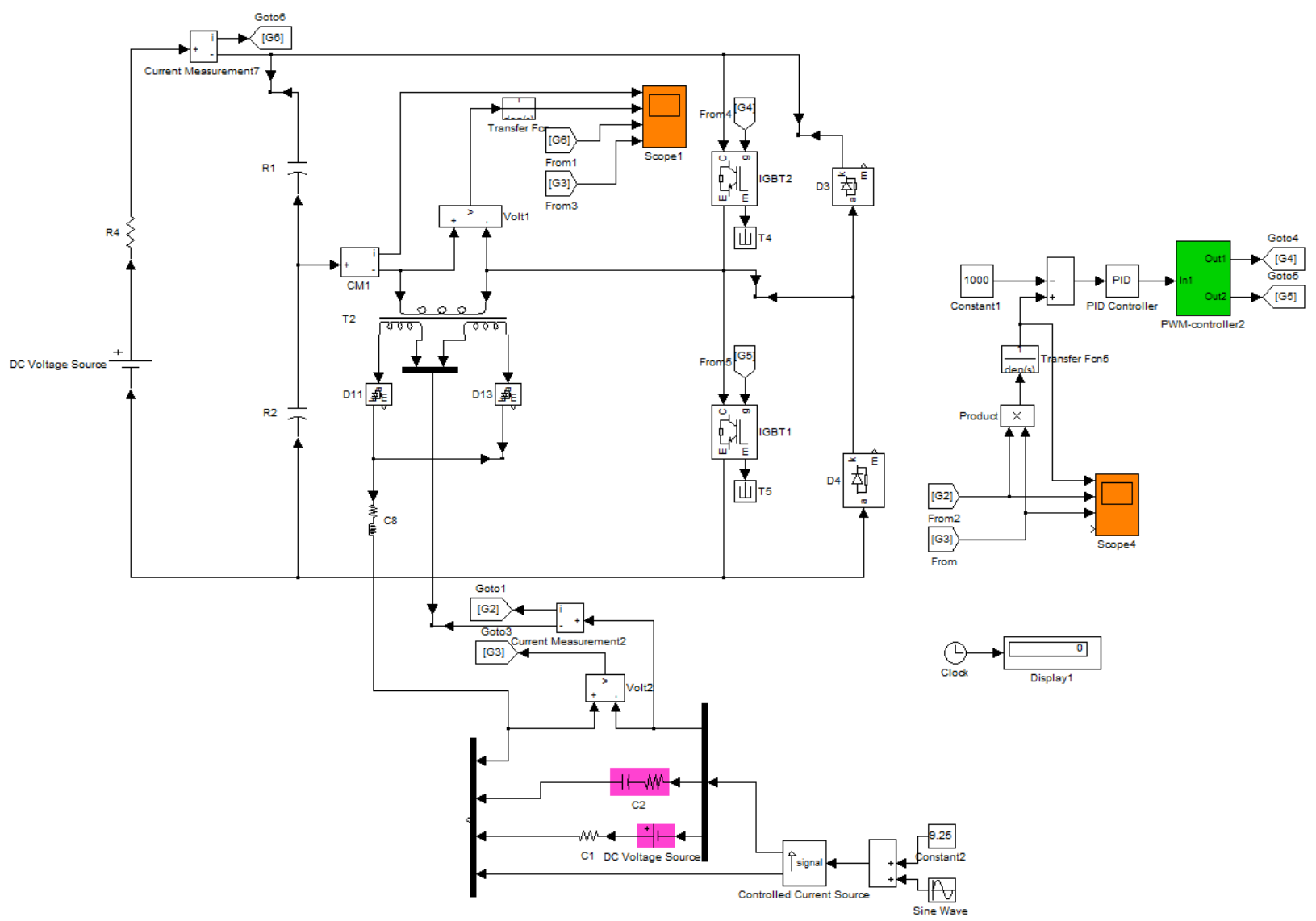

Figure 7. Converter simulation model.

\section{Results and Discussion}

The simulation results are presented by the timing diagrams of the autonomous inverter (Figure 8) and the voltage converter (Figures 9-11).

(a)

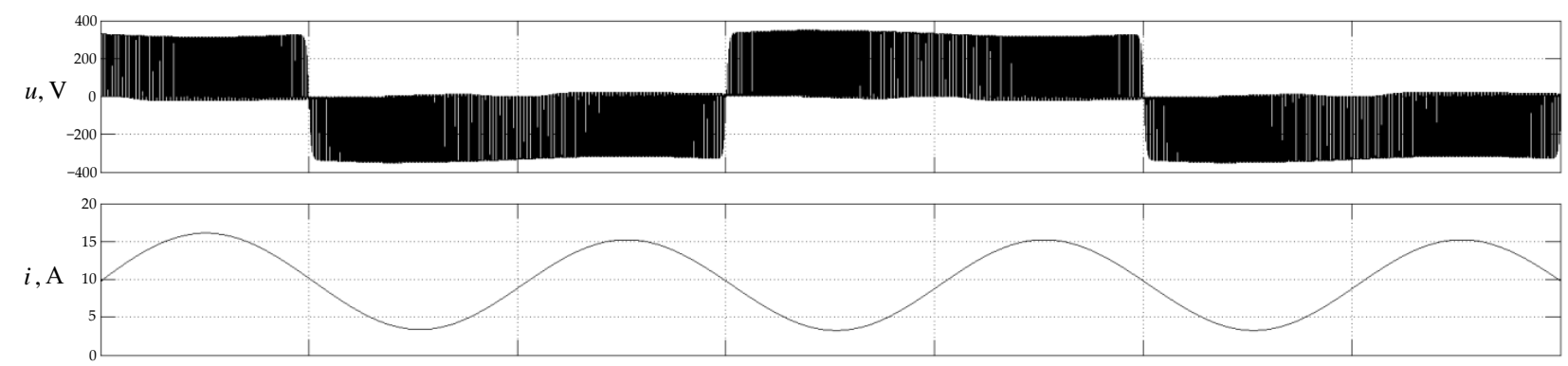

(c)

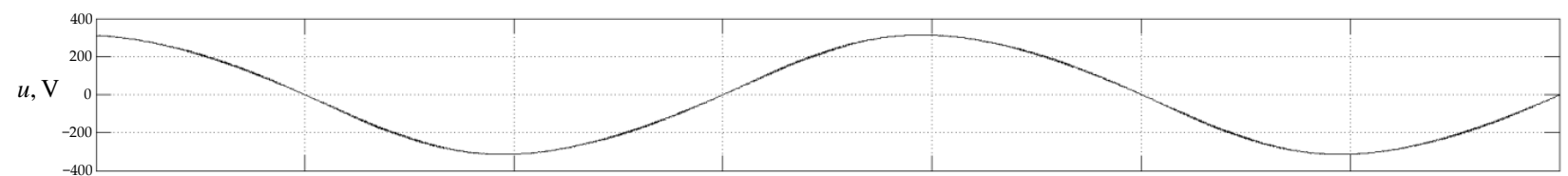

(d)

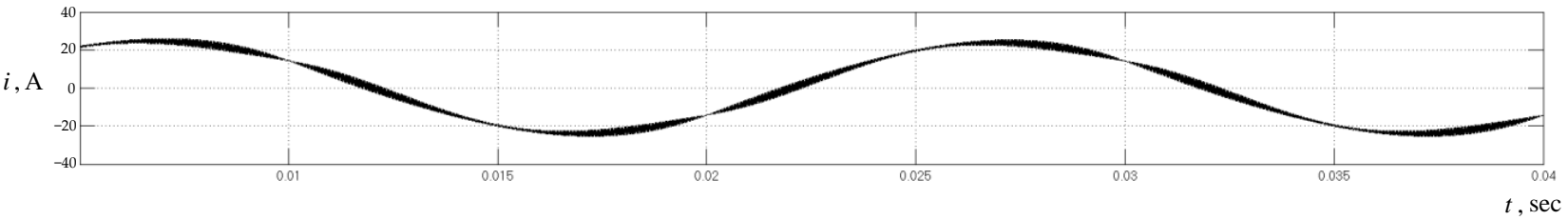

Figure 8. Output AVI operation diagrams: (a) AVI output voltage; (b) Battery current; (c) HFCGS output voltage; (d) AVI output current. 


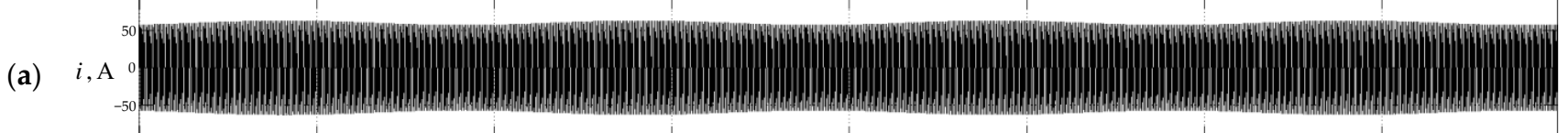

(b)

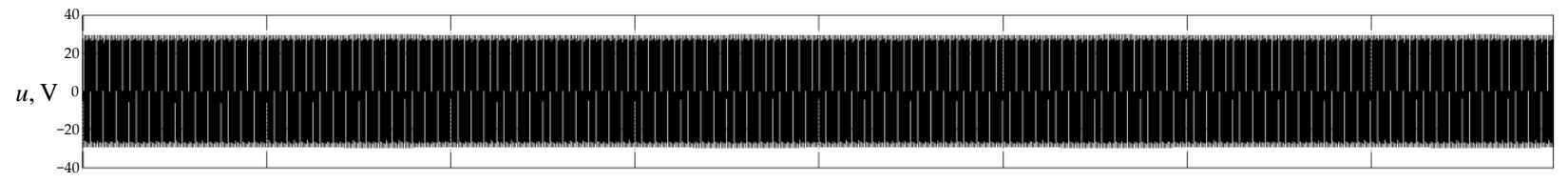

(c)

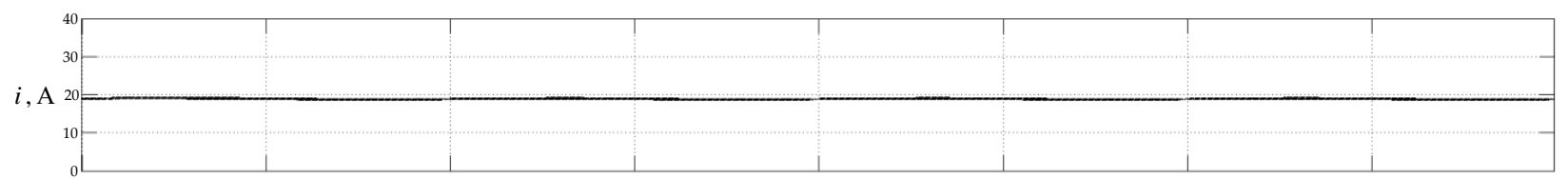

(d)

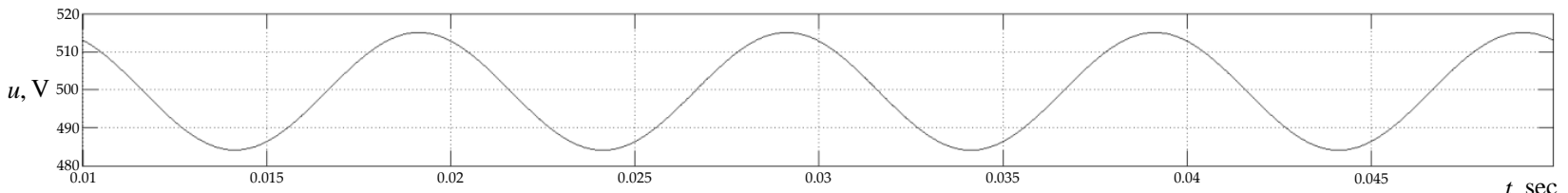

Figure 9. Converter operation diagrams: (a,b) Converter output current and voltage; (c) FC output current; (d) Battery voltage.

(a)

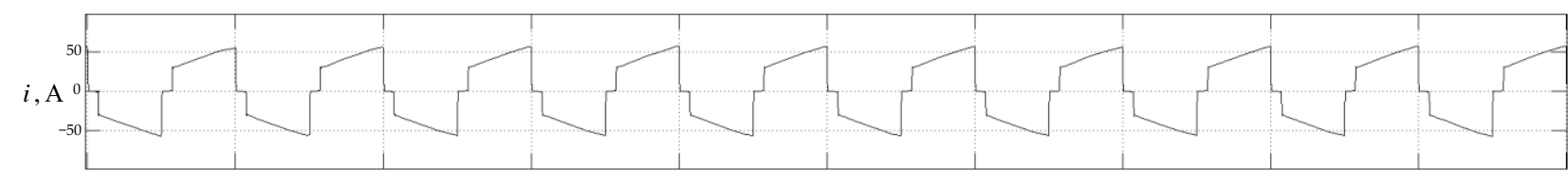

(b)

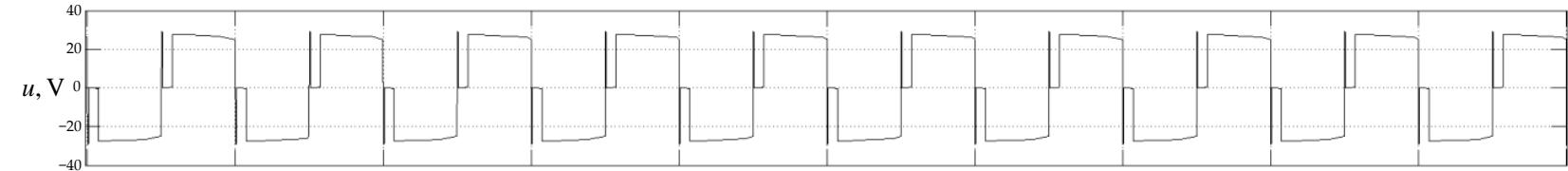

(c)

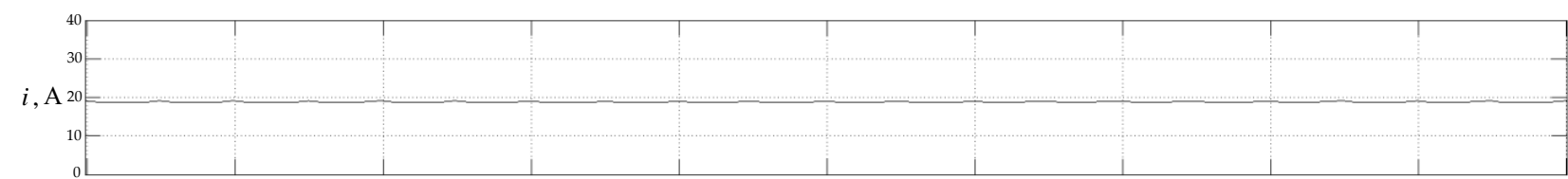

(d)

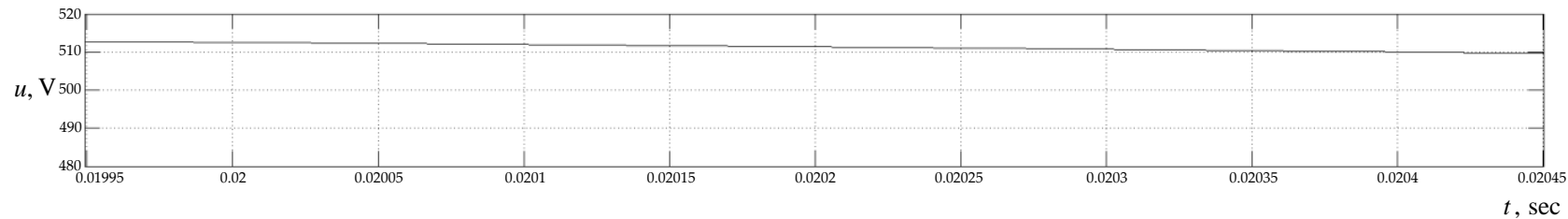

Figure 10. Converter operation diagrams: (a,b) Converter output current and voltage; (c) FC output current; (d) Battery voltage.

(a)

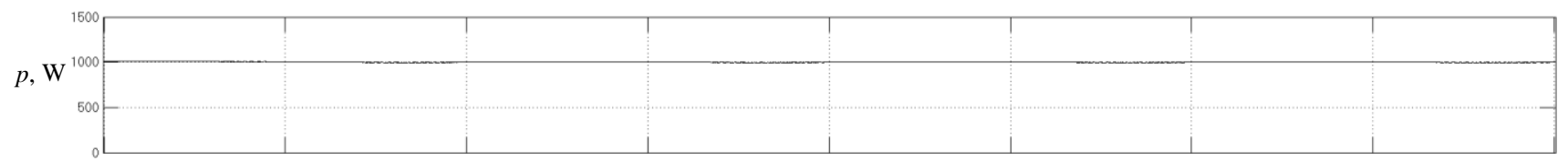

(b)

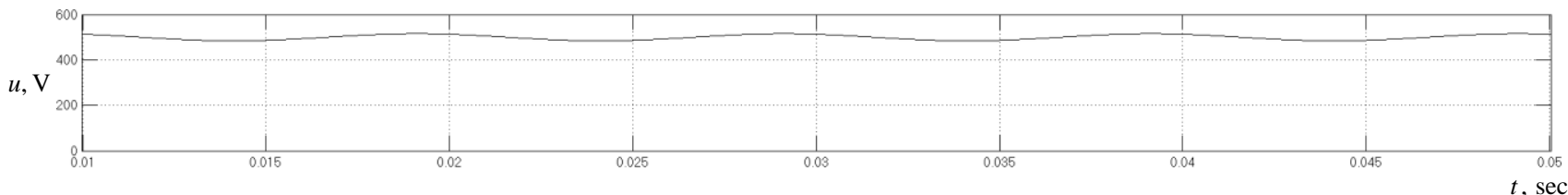

Figure 11. Converter operation diagrams: (a) Converter output power; (b) Battery voltage.

Figure 10 shows the same converter operation curves as in Figure 9, but for a $0.5 \mathrm{~ms}$ time interval. 
In addition to analyzing the instantaneous values of the current and voltages of the HFCGS's major components, an analysis of the harmonic components of the autonomous inverter output voltage has been carried out (Figures 12 and 13).
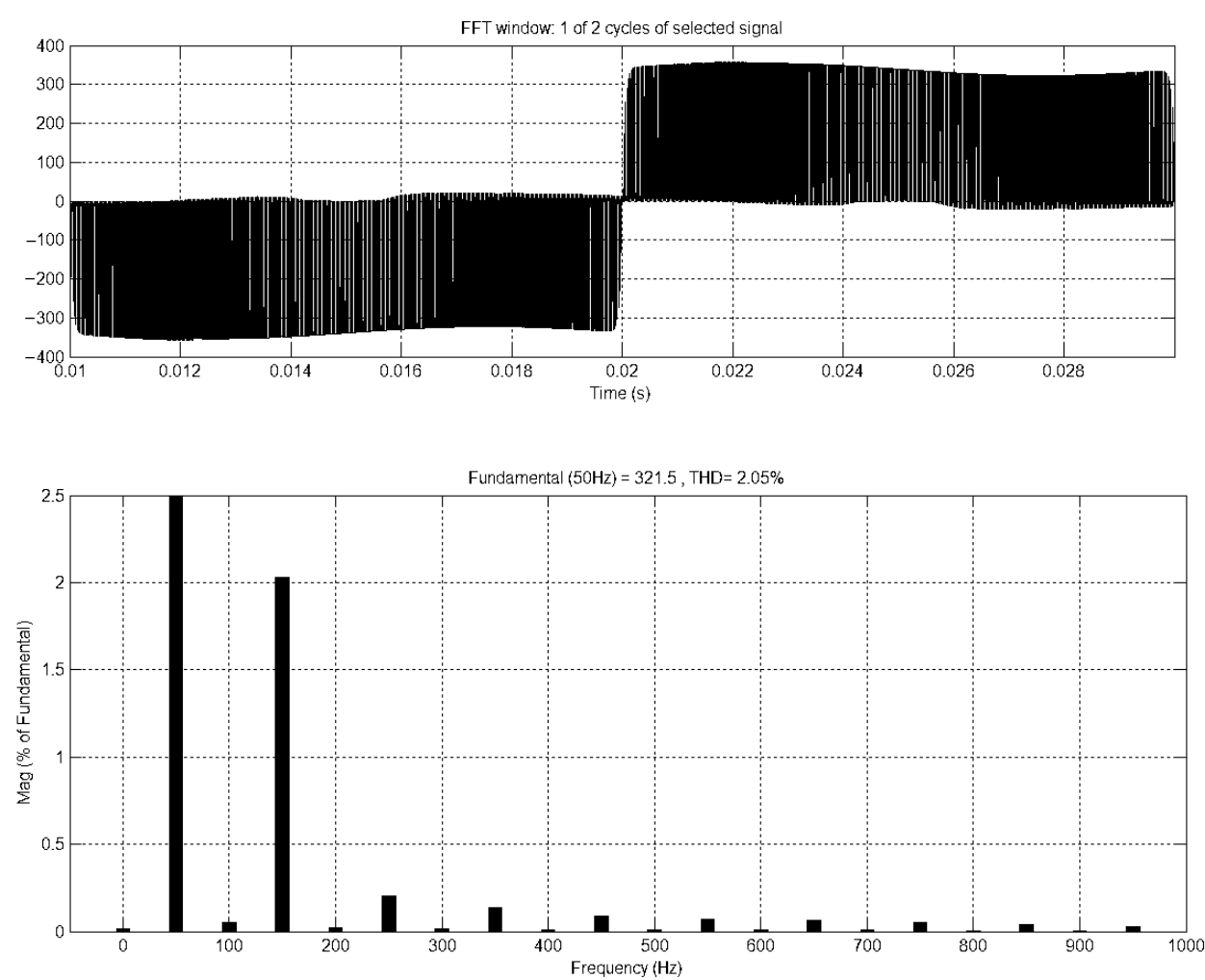

Figure 12. Spectral analysis of the HFCGS output voltage curve at $C_{2}=1000 \mu \mathrm{F}$.
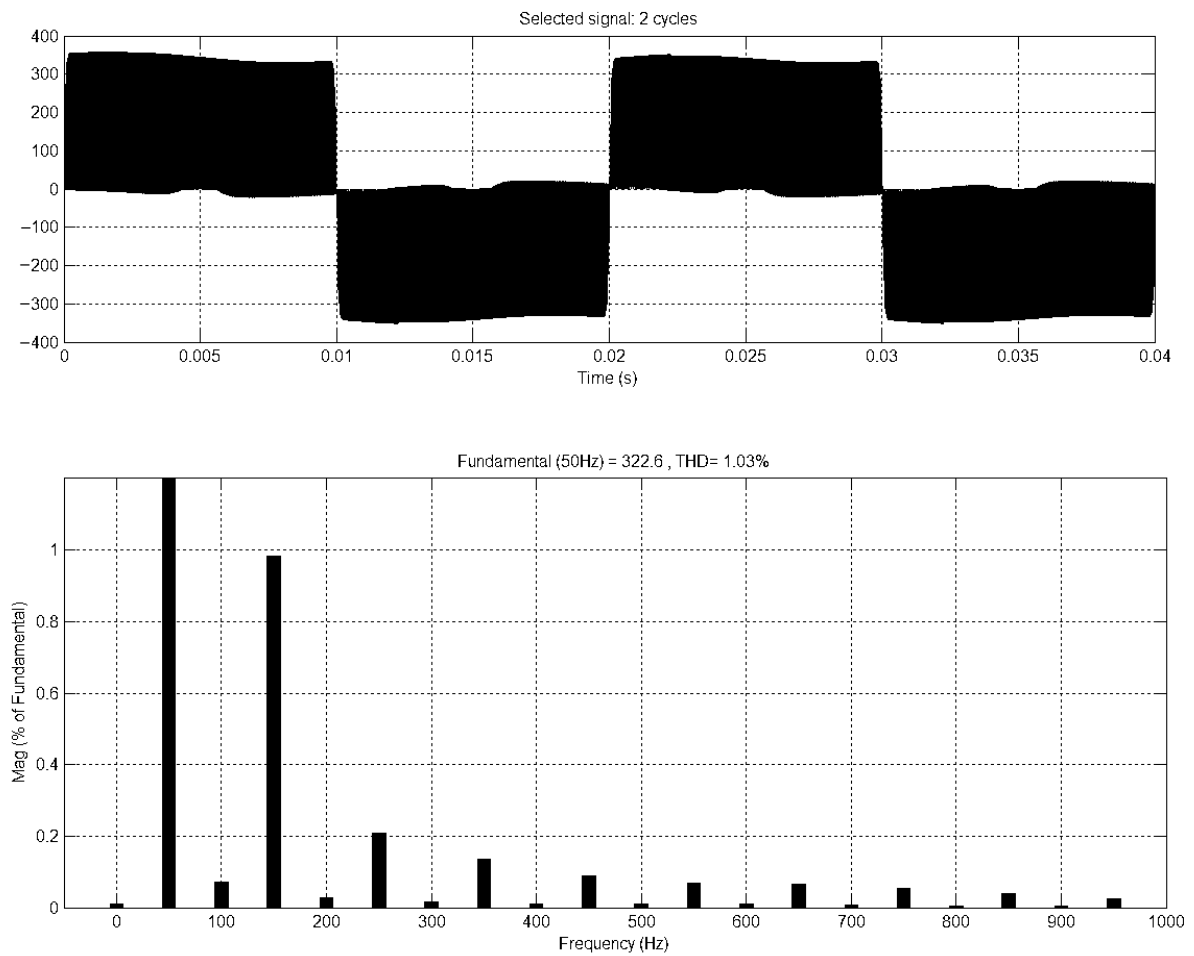

Figure 13. Spectral analysis of the HFCGS output voltage curve at $C_{2}=2000 \mu \mathrm{F}$. 
Figures 12 and 13 show that HFCGS output voltage contains a triple frequency component of $150 \mathrm{~Hz}$ in addition to the first frequency harmonic $50 \mathrm{~Hz}$ due to the AVI supply voltage amplitude modulation. The third harmonic amplitude at the selected values of $C 1$ and $C 2$ capacitances does not exceed $1-2 \%$ of the first harmonic.

The simulation results confirmed the considered HFCGS structure's operability, the reliability of its parameter calculations and the high quality of its output voltage.

\section{Cost Estimation of Electric Power Generated by Hydrogen Fuel Cell Generation System}

The levelized cost of energy (LCOE) was calculated to analyze the HFCGS's competitiveness as follows:

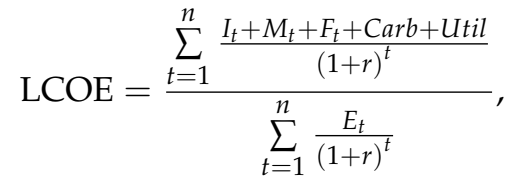

where $I_{t}$ is the annual investment (capital) costs, USD; $M_{t}$ is the annual operating costs and maintenance costs, USD; $F_{t}$ is the annual fuel costs, USD; $E_{t}$ is the annual quantity of generated electric energy, $\mathrm{kWh}$; Carb is the annual cost of greenhouse gas emission (carbon footprint); Util is the decommissioning charge after the HFCGS end-of-life; $r$ is the discount rate; and $t=1, \ldots, n$ is the service life.

The following factors affect the cost per unit of electrical energy generated by a HFCGS:

- Hydrogen cost. The price of hydrogen may vary depending on the country of origin and the prices of fossil fuels in it, on the method of producing hydrogen (steam reforming of hydrocarbons, gasification of solid fuels, thermochemical decomposition of water using the energy of a high-temperature gas-cooled reactor (HTGR), electrolysis of water), its transportation (by pipeline or in cylinders) and its state (compressed or liquefied). The methods to produce hydrogen differ in the amount of costs for electricity, $\mathrm{H}_{2} \mathrm{O}$, natural gas, etc. In addition, each method of producing $\mathrm{H}_{2}$ is characterized by a different amount of $\mathrm{CO}_{2}$ emissions;

- The power of the hydrogen plant, its duty factor and its fuel consumption;

- Cost of greenhouse gas emissions and hydrogen plant utilization after the end of its life.

Table 6 provides a comparative analysis of various methods for producing hydrogen from the standpoint of specific energy consumption and carbon dioxide emissions.

Table 6. Comparative analysis of various methods for producing compressed hydrogen $[25,26]$.

\begin{tabular}{|c|c|c|c|c|c|c|}
\hline \multirow{2}{*}{$\begin{array}{c}\mathrm{H}_{2} \text { Production } \\
\text { Technology }\end{array}$} & \multicolumn{5}{|c|}{ Energy Consumption per $1 \mathrm{~kg} \mathrm{H}_{2}$} & \multirow{2}{*}{$\begin{array}{l}\mathrm{CO}_{2} \text { Emission pe } \\
\quad 1 \mathrm{~kg} \mathrm{H}, \mathrm{kg}\end{array}$} \\
\hline & Natural Gas, $\mathrm{m}^{3}$ & Coal, kg & $\mathrm{H}_{2} \mathrm{O}, \mathrm{kg}$ & $\begin{array}{c}\text { Electrical Energy, } \\
\text { kWh }\end{array}$ & $\begin{array}{c}\text { Thermal Energy, } \\
\text { kWh }\end{array}$ & \\
\hline $\begin{array}{l}\text { Steam methane } \\
\text { reformation }\end{array}$ & $5-5.5$ & - & $4-4.5$ & $0.7-0.9$ & - & 9.5 \\
\hline Coal gasification & - & $7-7.5$ & 9 & $0.7-0.8$ & - & 21 \\
\hline $\begin{array}{l}\text { Thermochemical } \\
\text { water splitting } \\
\text { based on HTGR }\end{array}$ & - & - & $9-20$ & $2-2.5$ & $60-65$ & 1.7 \\
\hline $\begin{array}{l}\text { Electrolysis (from } \\
\text { an electrical } \\
\text { network) }\end{array}$ & - & - & 9 & $55-60$ & - & 41.1 \\
\hline $\begin{array}{l}\text { Electrolysis (from a } \\
\text { wind turbine) }\end{array}$ & - & - & 9 & $55-60$ & - & - \\
\hline $\begin{array}{l}\text { Electrolysis (from a } \\
\text { solar energy station) }\end{array}$ & - & - & 9 & $55-60$ & - & - \\
\hline
\end{tabular}

To obtain liquefied hydrogen, it is necessary to spend three to seven times more electricity than to obtain compressed gaseous hydrogen. This also increases $\mathrm{CO}_{2}$ emissions. 
Table 7 provides an estimate of the energy resources cost, the specific investments for hydrogen production and the cost of transporting hydrogen fuel.

Table 7. Cost value estimation of hydrogen production [25-28].

\begin{tabular}{cc}
\hline Parameters & Value \\
\hline \multicolumn{1}{c}{ Energy prices } & 111 \\
\hline Natural gas, thousand $\mathrm{m}^{3}$ & 112 \\
\hline Coal, USD/ton & 0.05 \\
\hline $\begin{array}{c}\text { Electric energy from a centralized source, } \\
\text { USD/kWh }\end{array}$ & 500 \\
\hline Specific capital investment in auxiliary energy sources \\
\hline HTGR, USD/kW (thermal power) & 1000 \\
\hline Solar power plants (SPP), USD/kW & 500 \\
\hline Wind power plants (WPP), USD/kW & 740 \\
\hline Specific investment in elements of hydrogen production technology \\
\hline Electrolyser, USD/kW & $25-30$ \\
\hline Methane reformer, USD/kg $\mathrm{H}_{2}$ & 2000 \\
\hline Hydrogen compressor, USD/kW & 1100 \\
\hline H ${ }_{2}$ liquefaction unit, USD/kg H $/$ day & 0.09 \\
\hline The cost of transporting hydrogen per $100 \mathrm{~km}$ \\
\hline Liquefied by auto transportation in cryogenic \\
tanks, USD/kg
\end{tabular}

The change in the cost of compressed hydrogen production for various technologies depending on the volume of hydrogen production is shown in Figures 14 and 15 [25,29,30].

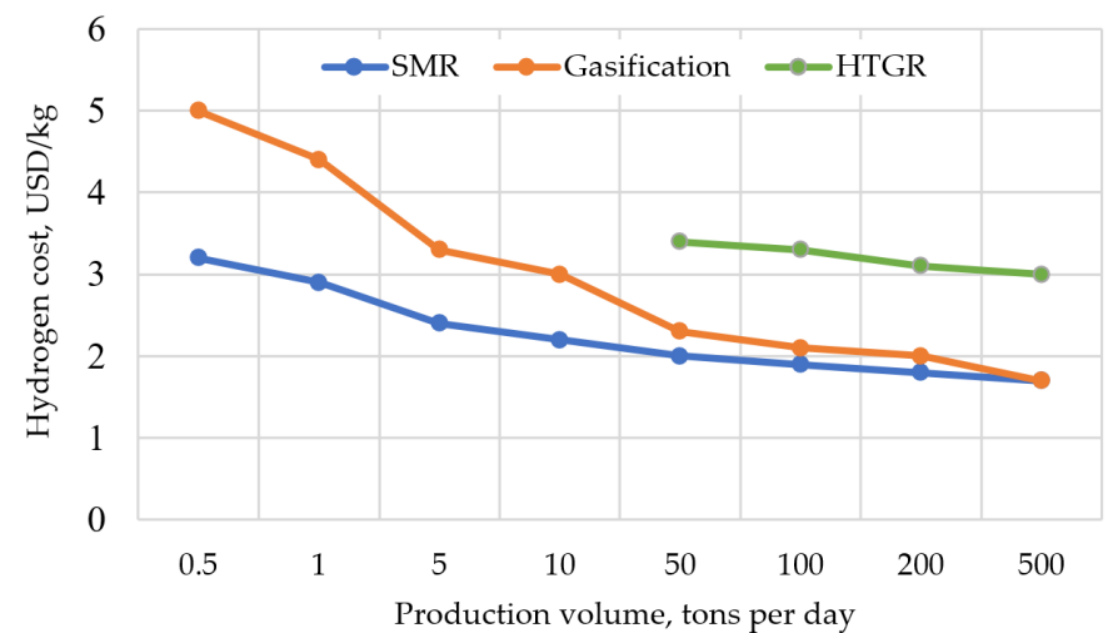

Figure 14. Cost of hydrogen production for steam methane reformation (SMR) technologies, coal gasification and thermochemical water decomposition using HTGR. 


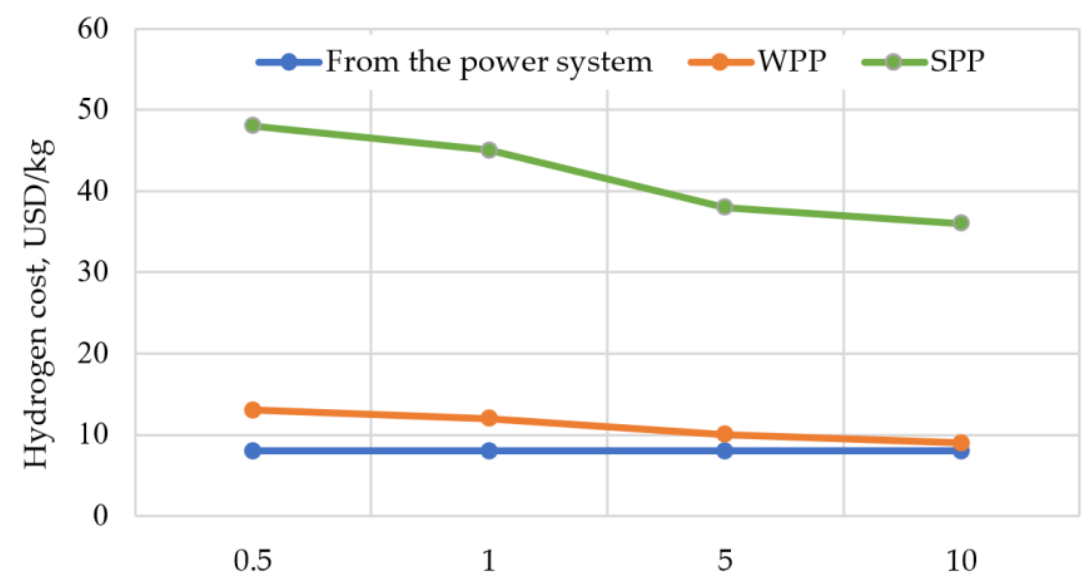

Figure 15. Cost of producing compressed hydrogen for water electrolysis technologies based on electric energy from the network and renewable energy sources.

Thus, regardless of the volume of hydrogen production, the cheapest method is the method of steam methane reformation (SMR). The cost of hydrogen starts from $3 \mathrm{USD} / \mathrm{kg}$ $\mathrm{H}_{2}$ at low capacities of SMR units, but with a capacity of more than 500 tons per day, it decreases to $1.7 \mathrm{USD} / \mathrm{kg} \mathrm{H}_{2}$. Hydrogen production process by coal gasification at low productivity is strongly inferior to SMR, although at high productivity the coal option is practically equal to the SMR method. The method of thermochemical decomposition of water based on HTGR is applicable only at capacities of more than $35-50$ tons $\mathrm{H}_{2}$ per day. In this case, the cost of hydrogen turns out to be at least $3 \mathrm{USD} / \mathrm{kg} \mathrm{H}_{2}$. The hydrogen production based on electrolysis is significantly inferior in cost indicators to the methods discussed above.

The cost of electrolytic hydrogen turns out to be much higher: from $7-8 \mathrm{USD} / \mathrm{kg}$ $\mathrm{H}_{2}$ when operating on electric energy from the power system to 9-13 USD $/ \mathrm{kg} \mathrm{H}$ when receiving electricity from wind power plants and up to 35-50 USD/ $\mathrm{kg} \mathrm{H}_{2}$ when using photovoltaic converters as electricity source.

The specific costs of hydrogen transportation is shown in Figure 16. The liquefaction of hydrogen allows for reducing transportation costs by two to five times as compared to the option of compressed hydrogen. Likewise, hydrogen production and the cost of transport will depend on the pace of technology development and cost reduction [31].

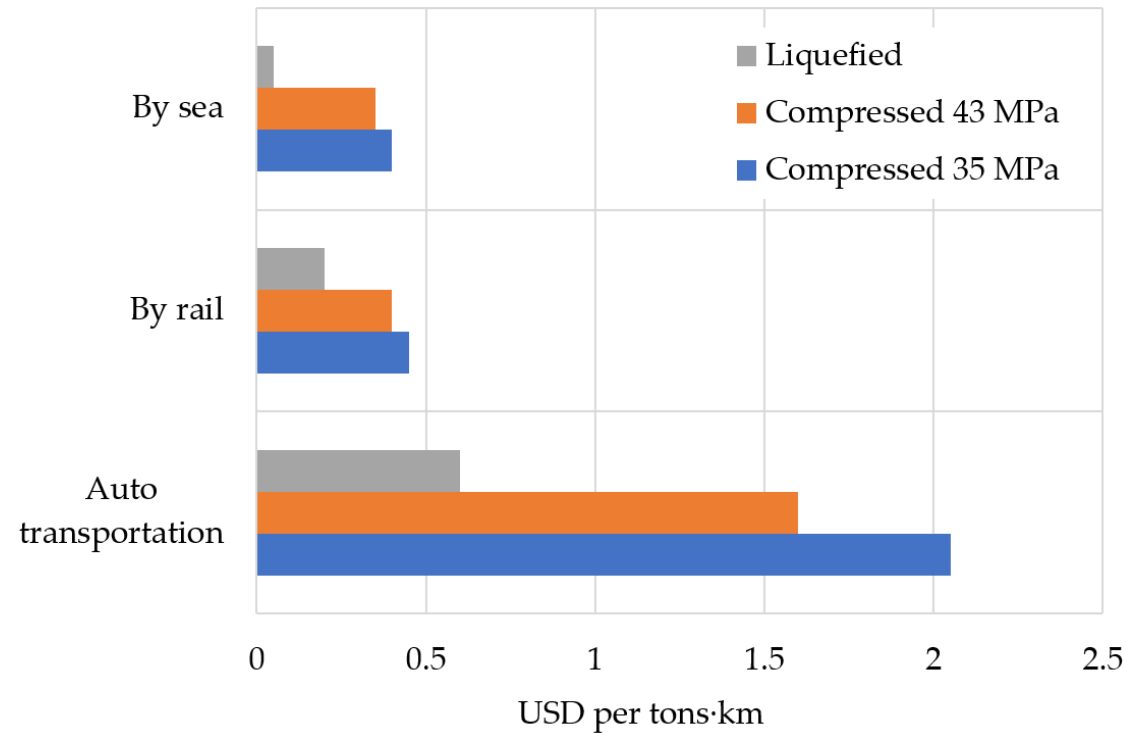

Figure 16. Specific cost of hydrogen transportation in different forms by various transport. 
Table 8 shows hydrogen cost estimation results obtained by Russian scientists compared to data from foreign publications. The total hydrogen cost values calculated by foreign researchers appears more optimistic for most technologies, as shown by Table $8[25,27,31]$.

Table 8. Comparison of the hydrogen cost estimation results by Russian specialists with global data.

\begin{tabular}{|c|c|c|c|}
\hline \multirow{2}{*}{\multicolumn{2}{|c|}{ Hydrogen Production Technology }} & \multicolumn{2}{|c|}{ Hydrogen Cost, USD/kg $\mathrm{H}_{2}$} \\
\hline & & Estimates of Russian Experts & Estimation of Global Experts \\
\hline \multirow{6}{*}{ 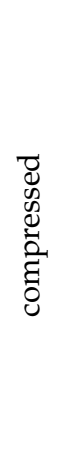 } & SMR (natural gas) & $1.2-2.7$ & $1.8-3.5$ \\
\hline & Coal gasification & $1.9-2.3$ & 1.6 \\
\hline & $\begin{array}{l}\text { Thermochemical water } \\
\text { splitting with HTGR }\end{array}$ & $3.3-7.5$ & $1.0-1.6$ \\
\hline & $\begin{array}{c}\text { Electrolysis (from an electrical } \\
\text { network) }\end{array}$ & $4.3-9.3$ & 4.7 \\
\hline & $\begin{array}{l}\text { Electrolysis (from a wind } \\
\text { turbine) }\end{array}$ & $4.4-25.9$ & $3.9-7.1$ \\
\hline & $\begin{array}{c}\text { Electrolysis (from a solar } \\
\text { energy station) }\end{array}$ & $7.1-50$ & $6.4-25.8$ \\
\hline \multirow{6}{*}{ 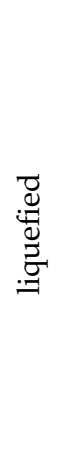 } & SMR (natural gas) & $2.9-4.4$ & 3.8 \\
\hline & Coal gasification & $3.8-4.1$ & $4.5-5.1$ \\
\hline & $\begin{array}{l}\text { Thermochemical water } \\
\text { splitting with HTGR }\end{array}$ & $5.7-10.2$ & $1.4-2.1$ \\
\hline & $\begin{array}{c}\text { Electrolysis (from an electrical } \\
\text { network) }\end{array}$ & $5.7-11.6$ & 7.8 \\
\hline & $\begin{array}{c}\text { Electrolysis (from a wind } \\
\text { turbine) }\end{array}$ & $6.0-31.3$ & $4.5-9.5$ \\
\hline & $\begin{array}{l}\text { Electrolysis (from a solar } \\
\text { energy station) }\end{array}$ & $9.1-60.0$ & 7.5 \\
\hline
\end{tabular}
Table 9.

The initial data for calculating electric energy cost from the HFCGS are given in

Table 9. Initial data for electric energy cost calculation.

\begin{tabular}{cc}
\hline Parameter & Value \\
\hline Fuel cell power, $\mathrm{kW}$ & 1 \\
\hline Hydrogen consumption, liters per minute & 12 \\
\hline Hydrogen source service life, years & 10 \\
\hline $\begin{array}{c}\text { The total cost of hydrogen source experimental } \\
\text { sample (with hydrogen generator), thousand USD }\end{array}$ & 50 \\
\hline Distilled water cost, USD $/ \mathrm{m}^{3}$ & 18 \\
\hline Inflation rate, $\%$ & 5.1 \\
\hline
\end{tabular}

The investment costs consist of the HFCGS components cost (fuel cell, batteries, converters, hydrogen generator) and the cost of installation and commissioning. A hydrogen generator based on electrolysis with a $12 \mathrm{~L}$ per minute capacity serves as a source of

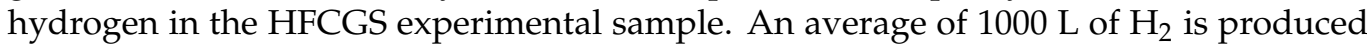
from $1 \mathrm{~L}$ of distilled water according to its technical parameters.

The operating and maintenance costs of HFCGS include the cost of source services. 
The costs of paying for greenhouse gas emissions and the costs of HFCGS decommissioning after the end of service life are taken as equal to 0.

$\mathrm{LCOE}=1.17 \mathrm{USD} / \mathrm{kWh}$ is calculated substituting the values from Table 9 into Equation (20).

Figure 17 shows the LCOE for diesel, gasoline and hydrogen power plants of the equal capacity.

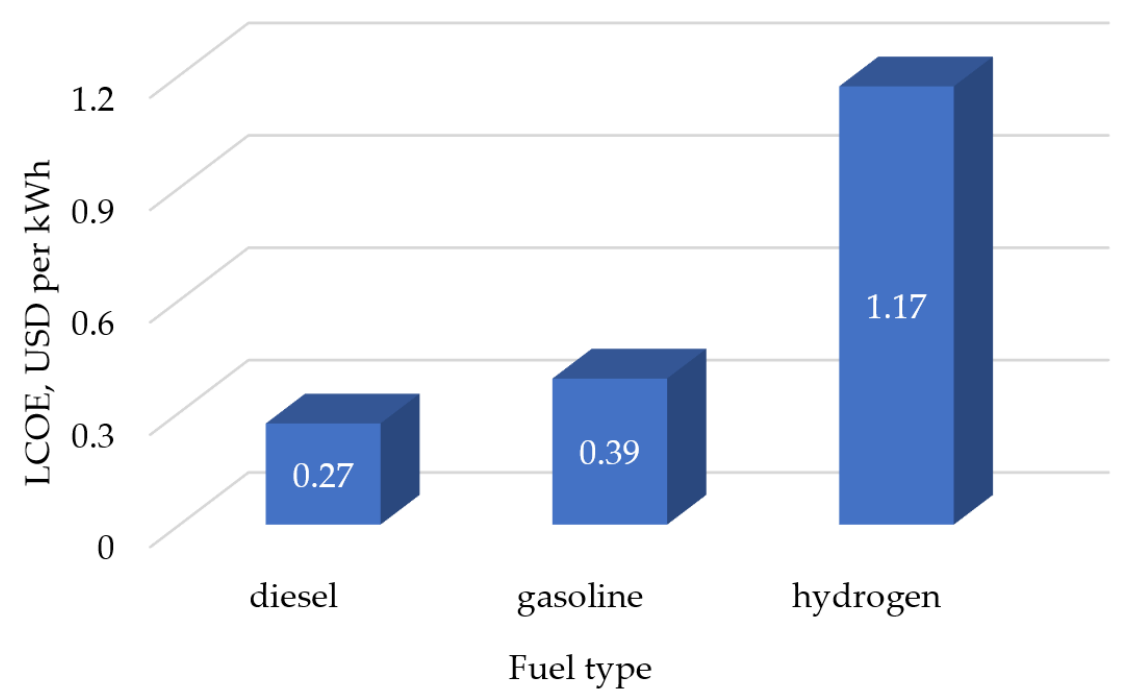

Figure 17. LCOE for diesel, gasoline and hydrogen power plants of the equal capacity.

\section{Conclusions}

The paper presents results of the structure development and choice of the optimal composition of a hydrogen generation system based on fuel cells and an accumulation system, as well as the research results of its operation modes.

The structural and functional diagrams of the hydrogen fuel cell generation system have been developed. One of the main elements of the HFCGS is fuel cells, the PEMFC type being the most suitable ones. They are characterized by a high rate of load change, ease of operation and the ability to work in a wide range of ambient temperatures. A sequential assembly of $12 \mathrm{LiFePO}_{4} 36 \mathrm{~V} 3.5 \mathrm{Ah}$ batteries is defined as a buffer storage system for HFCGS, providing the required level of output power together with the fuel cell. The HFCGS power circuit also includes a converter and an output autonomous voltage inverter with PWM. The proposed scheme eliminates the need to install an additional converter for matching batteries and HFCGS voltages, which significantly simplifies the HFCGS, stabilizes its operation and improves the weight-size parameters.

The parameters calculation of the device elements has been performed-filter capacitors, converter, autonomous voltage inverter, fuel cells and batteries. The HFCGS simulation model was built to test the operability of the considered structure using the obtained parameters. The operation diagrams of the output autonomous voltage inverter, converter, as well as the spectral analysis of HFCGS output voltage curve have been constructed. It was found that the HFCGS output voltage contains the third harmonic and its value does not exceed $1-2 \%$ of the amplitude of the fundamental harmonic. The simulation results confirmed the operability of the considered HFCGS structure, the reliability of its parameter calculations and a high quality of output voltage.

The cost estimation of the electric power generation by the hybrid energy complex has been carried out. It exceeds the electric energy cost from power plants running on gasoline and diesel. It has been established that the electric energy cost is influenced by both the cost of energy source itself and the hydrogen cost. This allows us to identify two important directions in reducing the electric energy cost-improving the elements that make up a hydrogen source (fuel cells, converters, batteries, etc.) and development methods of more efficient ways of hydrogen production. 
Author Contributions: Conceptualization, A.K. (Aleksandr Kulikov) and A.L.; methodology, A.K. (Andrey Kurkin) and A.K. (Andrey Kozelkov); software, V.V.; validation, A.S. (Andrey Shahov), A.S. (Andrey Shalukho), R.B., A.K. (Andrey Kozelkov) and E.K.; formal analysis, A.S. (Andrey Shalukho) and E.K.; investigation, V.V.; resources, I.L.; data curation, R.B., A.D. and I.L.; writing-original draft preparation, A.K. (Aleksandr Kulikov), A.L., A.S. (Andrey Shalukho), E.K. and I.L.; writingreview and editing, A.L.; visualization, R.B.; supervision, A.L. and A.D.; project administration, A.K. (Aleksandr Kulikov) and A.L.; funding acquisition, A.K. (Aleksandr Kulikov) and A.K. (Andrey Kurkin). All authors have read and agreed to the published version of the manuscript.

Funding: The reported study was funded by RFBR, Sirius University of Science and Technology, JSC Russian Railways and Educational Fund "Talent and success", project number 20-38-51016 and Council of the grants of President of the Russian Federation for the state support of Leading Scientific Schools of the Russian Federation (Grant No. NSH-2485.2020.5).

Institutional Review Board Statement: Not applicable.

Informed Consent Statement: Not applicable.

Data Availability Statement: There are no publicly available data that should be provided.

Conflicts of Interest: The authors declare no conflict of interest.

\section{References}

1. Voropay, N.I. Prospects and problems of electric power system transformations. Electrichestvo 2020, 7, 12-21. [CrossRef]

2. Pethaiah, S.S.; Sadasivuni, K.K.; Jayakumar, A.; Ponnamma, D.; Tiwary, C.S.; Sasikumar, G. Methanol electrolysis for hydrogen production using polymer electrolyte membrane: A mini-review. Energies 2020, 13, 5879. [CrossRef]

3. Sosnina, E.; Shalukho, A.; Veselov, L. Application of SOFCs on biogas in power supply systems for agricultural enterprises. Smart Electr. Eng. 2020, 4, 27-41. [CrossRef]

4. Hemmes, K. A personal retrospect on three decades of high temperature fuel cell research; ideas and lessons learned. Int. J. Hydrogen Energy 2021, 46, 14962-14976. [CrossRef]

5. Zhou, S.; Cui, Q.; Zhang, M.; Xia, G.; Wang, K. Study on the management of fuel cell vehicle energy system using hybrid fuzzy logic controller. Power Gener. Technol. 2018, 39, 554-560. [CrossRef]

6. Li, G.; Chen, J.; Zheng, X.; Xiao, C.; Zhou, S. Research on energy management strategy of hydrogen fuel cell vehicles. In Proceedings of the 2020 Chinese Automation Congress (CAC), Shanghai, China, 6-8 November 2020; pp. 7604-7607. [CrossRef]

7. Choi, H.-J.; Park, S.-J.; Choi, J.-S.; Cha, I.-S.; Yoon, J.-P.; Suh, J.-S.; Gun, S.-D. An analysis of PEMFC \& photovoltaic $500 W$ hybrid system. In Proceedings of the 7th International Conference on Power Electronics, Daegu, Korea, 22-26 October 2007; pp. 522-524. [CrossRef]

8. Khurshid, O.; Saher, S.; Qamar, A. Power generation by hybrid approach solar PV/battery power/hydrogen generation/fuel cell. In Proceedings of the 2019 International Conference on Electrical, Communication, and Computer Engineering (ICECCE), Swat, Pakistan, 24-25 July 2019; pp. 1-4. [CrossRef]

9. Wilson, P.R.; Wilcock, R. Hybrid hydrogen fuel cell and photo-voltaic system for remote telecommunications applications. In Proceedings of the 2013 4th IEEE International Symposium on Power Electronics for Distributed Generation Systems (PEDG), Rogers, AR, USA, 8-11 July 2013; pp. 1-4. [CrossRef]

10. Taoufikl, M.; Lassad, S. Hybrid photovoltaic-fuel cell system with storage device control. In Proceedings of the 2017 International Conference on Green Energy Conversion Systems (GECS), Hammamet, Tunisia, 23-25 March 2017; pp. 1-6. [CrossRef]

11. Rao, T.E.; Elango, S.; Swamy, G.G. Power management strategy between PV-Wind fuel hybrid system. In Proceedings of the 2021 7th International Conference on Electrical Energy Systems (ICEES), Chennai, India, 11-13 February 2021; pp. 101-107. [CrossRef]

12. Wang, B.; Xian, L.; Manandhar, U.; Ye, J.; Ukil, A.; Gooi, H.B. A stand-alone hybrid PV-fuel cell power system using single-inductor dual-input single-output boost converter with model predictive control. In Proceedings of the 2017 Asian Conference on Energy, Power and Transportation Electrification (ACEPT), Singapore, 24-26 October 2017; pp. 1-5. [CrossRef]

13. Wang, Y.-X.; Ou, K.; Qin, F.-F.; Kim, Y.-B. Proton exchange membrane fuel cell protection control for its hybrid power system application. In Proceedings of the 2015 IEEE PES Asia-Pacific Power and Energy Engineering Conference (APPEEC), Brisbane, Australia, 15-18 November 2015; pp. 1-5. [CrossRef]

14. Loskutov, A.; Sosnina, E.; Chivenkov, A.; Kryukov, E. The development of hybrid power source based on SOFC for distant electricity consumers power supply. In Proceedings of the 2015 IEEE Innovative Smart Grid Technologies-Asia (ISGT ASIA), Bangkok, Thailand, 3-6 November 2015; pp. 1-6. [CrossRef]

15. Filippov, S.; Golodnitsky, A.; Kashin, A. Fuel cells and hydrogen energy. Energy Policy 2020, 11, 28-39. [CrossRef]

16. Faizan, M.; Ali, S.; Ahmad, D.A. An overview of fuel cell based distribution generation integration. In Proceedings of the 2019 International Conference on Power Electronics, Control and Automation (ICPECA), New Delhi, India, 16-17 November 2019; pp. 1-6. [CrossRef]

17. Giorgi, L.; Leccese, F. Fuel cells: Technologies and applications. Open Fuel Cells J. 2013, 6, 1-20. [CrossRef] 
18. Jayakumar, A. An assessment on polymer electrolyte membrane fuel cell stack components. In Applied Physical Chemistry with Multidisciplinary Approaches, 1st ed.; Haghi, A.K., Balkose, A., Thomas, S., Eds.; Apple Academic Press: Boca Raton, FL, USA, 2018; pp. 23-49. [CrossRef]

19. Jayakumar, A. A comprehensive assessment on the durability of gas diffusion electrode materials in PEM fuel cell stack. Front. Energy 2019, 13, 325-338. [CrossRef]

20. Chaudhary, S.; Chauhan, Y.K. Studies and performance investigations on fuel cells. In Proceedings of the 2014 International Conference on Advances in Engineering \& Technology Research (ICAETR-2014), Unnao, India, 1-2 August 2014; pp. 1-6. [CrossRef]

21. Lee, S.C.; Kwon, O.; Lee, D. Fuel cell simulation: Steady-state and dynamic case. In Proceedings of the 20127 th International Conference on Computer Science \& Education (ICCSE), Melbourne, Australia, 14-17 July 2012; pp. 974-979. [CrossRef]

22. Sohn, S.; Oh, J.; Lee, Y.; Park, D.; Oh, I. Design of a fuel-cell-powered catamaran-type unmanned surface vehicle. IEEE J. Ocean. Eng. 2015, 40, 388-396. [CrossRef]

23. Guaitolini, S.V.M.; Yahyaoui, I.; Fardin, J.F.; Encarnação, L.F.; Tadeo, F. A review of fuel cell and energy cogeneration technologies. In Proceedings of the 2018 9th International Renewable Energy Congress (IREC), Hammamet, Tunisia, 20-22 March 2018; pp. 1-6. [CrossRef]

24. Dongguan Power Long Battery Technology Co, Ltd. (PLB). Available online: http://www.plb-battery.com/battery-cells/3-2v-35 00mah-lifepo4-lfp-battery-cell-for.html (accessed on 2 June 2021).

25. Sinyak, Y.V. Modeling the cost of Hydrogen fuel in the conditions of its centralized production. In Hydrogen Energy Technologies: Materials of the Seminar of the Laboratory of Hydrogen Energy Technologies of the Joint Institute for High Temperatures of the Russian Academy of Sciences; Leontiev, A.I., Dunikov, D.O., Eds.; Federal State Budgetary Institution of Science Joint Institute for High Temperatures of the Russian Academy of Sciences (JIHT RAS): Moscow, Russia, 2017; Volume 1, pp. 39-56.

26. Mitrova, T.; Melnikov, Y.; Chugunov, D.; Glagoleva, A. The Hydrogen Economy-A Path towards Low Carbon Development; SKOLKOVO Energy Centre, Moscow School of Management SKOLKOVO: Moscow, Russia, 2019.

27. Christensen, A. Assessment of Hydrogen Production Costs from Electrolysis: United States and Europe; International Council on Clean Transportation: Berlin, Germany, 2020.

28. Glenk, G.; Reichelstein, S. Economics of converting renewable power to hydrogen. Nat. Energy 2019, 4, 216-222. [CrossRef]

29. Albrecht, U.; Barth, F.; Bünger, U.; Fraile, D.; Lanoix, J.-C.; Pschorr-Schoberer, E.; Vanhoudt, W.; Weindorf, W.; Zerta, M.; Zittel, W. Study on Hydrogen from Renewable Resources in the EU; Ludwig-Bölkow-Systemtechnik GmbH (LBST): Munich, Germany, 2015.

30. Grube, T.; Höhlein, B. Costs of making hydrogen available in supply systems based on renewables. In Hydrogen and Fuel Cell; Töpler, J., Lehmann, J., Eds.; Springer: Berlin/Heidelberg, Germany, 2016. [CrossRef]

31. ACIL Allen Consulting for ARENA. Opportunities for Australia from Hydrogen Exports. Available online: https://acilallen.com. $\mathrm{au} /$ projects/energy/opportunities-for-australia-from-hydrogen-exports (accessed on 2 June 2021). 